\title{
Hz. Muhammed ve Diğer Peygamberlere Yönelik Fazahat Girişimleri ve Alınan Tedbirler: Arşiv Belgelerine Dayalı Bir İnceleme
}

\author{
Fatih RUKANCI' - Hakan ANAMERİÇ**
}

\begin{abstract}
ÖZ
Makale, Osmanlı Devleti'nin son 70 y1lına tarihlenen ve konu ile ilgili olarak seçilmiş olan arşiv belgelerinin Hz. Muhammed'e yönelik iftira, itham hatta küfre varan hakaret girişimlerinin "fazahat" başlı̆̆1 altında değerlendirilip transkribe edilerek, konuyla ilgili literatür ile desteklenerek irdelenmesine dayanmaktadır. Arşiv belgelerinin kanıtlayıcı ve bilgi verici değerinin yanı sıra Osmanlı ve Cumhuriyet dönemi arşiv fonlarındaki konu ve kapsam çeşitliliğini de yansıtan araştırmada fazahat teşebbüsleri, münferit hezeyanlar, basın-yayın ve görsel faaliyetlere karşı devletin tepkisi, kovuşturması ve tedbirleri ortaya konulmaktadır. Bu bağlamda Osmanlı Devleti'nin dinî alandaki bürokratik mücadelesi, geçmişten günümüze kadar uzanan İslam dinini Hz. Muhammed üzerinden yıpratma girişimlerini önleme başarısı da örnek belgeler üzerinden anlaş1labilecektir. Ayrıca bu çalışma, İslamiyet'e yönelik fazahat girişimlerinin hangi yöntemler uygulanarak hayata geçirildiğini, hangi boyutlara ulaştığını idrak ederek bugün de bu konuda uyanık ve tedbirli davranmamız gerektiği noktasında arşiv belgelerine dayalı olarak aydınlatıcı bilgiler içermektedir. Zira bu faaliyetlerin geçmişi İslamiyet'in ilk yıllarına kadar uzanmakta ve sistemli olarak tekrarlanarak günümüze kadar devam etmektedir. Çalışmada T. C. Cumhurbaşkanlığı Devlet Arşivleri Başkanlığı Osmanlı ve Cumhuriyet Arşivi fonlarından belirlenen belgeler kullanılmış olup, söz konusu belgeler fazahata konu olan eylemlere göre gruplandırılarak kendi içerisinde kronolojik bir sıraya konulmuştur.
\end{abstract}

Prof. Dr., Ankara Üniversitesi, Dil ve Tarih-Coğrafya Fakültesi, Bilgi ve Belge Yönetimi Bölümü, Ankara/Türkiye, frukanci@gmail.com ORCID: 0000-0002-9555-0747

** Prof. Dr., Ankara Üniversitesi, Dil ve Tarih-Coğrafya Fakültesi Bilgi ve Belge Yönetimi Bölümü, Ankara/Türkiye

hakananameric@gmail.com, ORCID: 0000-0001-9431-4403, DOI: 10.32704/erdem.948925

Makale Gönderim Tarihi: 11.08.2020 * Makale Kabul Tarihi: 26.03.2021 * (Araştırma Mk.) 
Söz konusu belgeler yanlış anlaşılmalara mahal verilmemesi için mümkün olduğu kadar aslına uygun şekilde konuyla ilgili yayınlanmı̧s çalışmalarla da desteklenerek özetlenmiştir. Bu bağlamda çalışmanın temel amac1, araştırmacılara her türlü siyasi, toplumsal, sosyolojik, kültürel vb. olayın açılanması ve belgelendirilmesinin arşivlerimizdeki zengin fonlar aracılığıyla yapılabileceğini ortaya koymaktır.

Anahtar Kelimeler: Hz. Muhammed, Osmanlı Devleti, İslamiyet, fazahat, arşiv belgesi, manevi değerler 


\title{
Measures Towards Disgrace Taken for Prophet Mohammed and also Other Prophets: An Evaluation Based on Archival Records
}

\begin{abstract}
The aim of the study is to examine the collection of archive documents from the last 70 years of the Ottoman State based on the evaluation and transcription of the slander, accusation and defamation attempts against Prophet Muhammad and also other prophets under the title "fazahat" (disgrace) and to investigate the subject by supporting it with the relevant literature. In addition to the evidential and informative value of archival documents, the research reflecting the diversity of subject and scope in our archival fonds of the Ottoman Republic shows the reaction of the state, the prosecution and measures against the individual delusions, the press and pictorial activity of "fazahat" attempts. In this context, the bureaucratic struggle of the Ottoman States in the religious sphere and its success in preventing the attempts to undermine the religion of Islam from the past to the present by the Prophet Muhammad can be understood on the basis of the sample documents. In addition, the study includes clarifications based on archive documents on where we should be vigilant and cautious about this issue today by understanding what methods have been implemented and what dimensions the impudent initiatives towards Islam have been applied. These activities date back to the early years of Islam and continue until today by being systematically repeated. In this study, documents from the Ottoman and Republican Era archival funds of the State Archives of the Presidency of the Republic of Turkey were used and these documents were grouped in chronological order according to the actions subject to the "fazahat". To avoid misunderstandings, the documents are summarized and supported by published works on the subject. The main aim of the study in this context is to remind the researcher with all kinds of political, social, sociologic, cultural, etc. that the disclosure and documentation of the event can be carried out through the rich resources in our archives.
\end{abstract}

Keywords: Hz. Muhammad (s.a.v.), Ottoman Empire, Islam, disgrace, archival records, spiritual values 
C alışma kapsamında, 1852-1923 arası yaklaşık 70 yıllık bir döneme ilişkin Hz. Muhammed'e ve diğer peygamberlere yönelik münferit fazahat girişimlerinin, küfrün (sebb), basın-yayın faaliyetlerinin, sinema, tiyatro, drama ve piyes gibi etkinliklerin engellenmesi, cezalandırılmasına dair tedbir ve diğer yaptırımlar, konuyla ilgili tespit edilen arşiv belgeleri çerçevesinde değerlendirilmiştir. Arşiv belgelerinin sahip olduğu bilgilendirici ve kanıtlayıcı değer, onları diğer bilgi kaynaklarından özellikle objektiflik ve güvenilirlik açısından çok farklı bir noktaya taşımaktadır. Tüm toplumların üzerinde hassasiyet gösterdiğini düşündüğümüz millî ve manevî meseleler kanıtlayıc1 belgelere dayalı olamadan tartışılıp açıklanmaya çalışıldı̆̆ı durumlarda bazen hakikat ya gizlenebilmekte ya da çarpıtılabilmektedir. Yalnızca kişisel birikim ve tarihsel bakış açısı çerçevesinde irdelenip çeşitli çıkarımlar yapmaya uygun olmayan bu araştırmanın kapsamı çerçevesinde ele alınan arşiv belgeleri ile sınırlı kalınarak belgeye dayalı bilgilendirme ve değerlendirme amacını taşıdığını belirtmekte yarar vardır. Çalışmaya belgesel kanıt desteği sunan arşiv belgeleri gerek dönem gerekse içerik itibariyle çeşitlendirilip, örneklendirilebilir. Dolayısıyla çalışmanın konusu ve ilişkili alt konuları ile ilgili yerli ve yabancı arşivlerde çok sayıda belge bulunabileceği tahmin edilmektedir. Bunun yanı sıra belirtilmesi gereken bir başka husus, arşiv belgelerine konu olan ve fazahat olarak nitelendirilen olumsuz tutum ve davranışların hiçbir şekilde genellemelere dayanak teşkil etmeyeceğinin bilinmesidir.

Fazahat, edepsizlik, alçaklık anlamlarında karşılık bulan "faziha” kelimesinin çoğuludur. Faziha; rezalet, ayıp, fena, çirkin, rezilane söz ve hareket anlamlarını taşımaktadır (Redhouse, 1856: 99; Devellioğlu, 1962: 302-303; Şemseddin Sâmî, 2001: 999). Sebep ne olursa olsun Hz. Muhammed'e ve İslam'ın değerlerine yönelik edep ve hakikat dışı her türlü faaliyetin karşılı̆̆ı en hafif tabiriyle "fazahat" kapsamında değerlendirilebilir.

Hz. Peygamber'e saygisızlık, her şeyden önce onu elçi olarak seçip gönderen Yüce Allah'a ve O'nun emirlerine sayg1sızlıktır. Bununla birlikte Hz. Peygamber’in şahsî ve manevî kimliğine saygısızlıktır. Dahası o peygamberi Allah'ın elçisi olarak bilen ve onun getirmiş olduğu ilahî buyruklarla hayatını idame ettiren milyonlarca mümin ve Müslüman bireyin maddî ve manevî kimlik, kişilik ve onurlarına saygısızlıktır (Özarslan, 2007: 71).

Batı dünyasının İslam'a yönelik reddetme, tahkir ve sahtelik iddiası, Batı düşüncesi boyunca çeşitlenerek teolojik tartışmalara, sanatsal ürünlere, resmi belgelere, değişik kültür alanlarına ve folklorik unsurlara sirayet etmiştir (Korkut, 2008: 6-7). Belgelerle somutlaştırılan bu girişimlerin günümüz- 
de farklı yöntemlerle, şekil değiştirerek devam ettiği söylenebilir. Bu fazahat girişimlerinin engellenmesine yönelik, inceleme, tahkikat ve yaptırımların bilinmesi hem arşivlerimizdeki konu çeşitliliğini ortaya koymak hem de konuya ilişkin güncel tedbirlerin gözden geçirilmesi açısından faydalı olacaktır.

a. Hz. Muhammed'e ve diğer peygamberlere yönelik kişisel fazahat eylemlerine örnek teşkil edecek belgeler:

\section{Cemaziyelevvel 1268/19 Mart 1852 tarihli Meclisi Vala mazbatasına ${ }^{1}$} göre: Ankara Valisi tarafindan Meclis-i Vala'ya gönderilen tahriratta Kayseri Meclisi mazbatası ve naibinin ilamından² anlaşıldığı üzere; Kayseri’nin İncesu kasabası ahalisinden Berber Mustafa oğlu Mehmed'in Peygamber efendimize küfretme rezilliğine cesaret ettiği kanıtlanmış olduğundan, adı geçen şakinin tövbesi kabul edilmemiş tehir edilmeksizin hadden katledilmesi için ferman çıkarılarak Vali’ye bildirilmesi gerekliliği belirtilmektedir (Belge-1).

İslam Hukuku'nda Hz. Peygamber'e hakaret eden bir kimse için öngörülen aslî cezalar ölüm cezası veya tazir cezasıdır. 1852 tarihli bu yazıda küfür yani sebb' suçunun kanıtlanmış olduğuna ve failin ya da fazihin tövbesinin kabul edilmeyeceğine vurgu yapılarak ta'zir; yani takdiren başka cezaya dönüştürülmeyerek ölüm cezasının uygulanması hakkında ferman çıkarılması istenmektedir (Yıldız, 2018: 150; Aydın, 2020: 51, 60). Hadden katledilme ifadesi ise; Allah hakkı ve toplum hakkı olarak herhangi bir hafifletmeye kimsenin yetkisinin olmadığı durumlar için kullanılmaktadır. Aynı türden suçların önüne geçmek maksadıyla uygulandığı için toplum üzerinde caydırıcı etkisine vurgu yapılarak had denilmiştir. Bu tür cezaların alt ve üst sınırı olmayıp kesindir (Köroğlu, 2015: 215-216).

\section{Eylül 1302/6 Ekim 1886 tarihinde Adliye Nazırı Ahmet Cevdet Paşa} tarafindan kaleme alınan cevabî (takrir) yazıda: Ekteki yazışmada adı geçen şahıs Hazret-i Peygambere sebb' (küfür)'e cesaret ve cüret eylemiş ise hakkındaki gizli tahkikat Sadaret'e bildirilmelidir. Ayrıca bu şahsın yaptığ1 rezillikten dolayı tahkikat belgeleri ile birlikte kanunda öngörülen cezanın uygulanması için ilgili adliyeye teslimi emredilmektedir (Belge-2).

\footnotetext{
${ }^{1}$ Bir meclis veya heyetin müzakerelerinin neticesini alınan hüküm veya karar, tasdik, bir madde hakkında danışma veya teşekkür gibi durumları bildirmek üzere bir makama hitaben kaleme alınan belgeler. Bakınız; Mübahat S. Kütükoğlu, Osmanlı Belgelerinin Dili (Diplomatik), 4. Baskı, Ankara: Türk Tarih Kurumu Yayınları, s. 324, 2018.

2 Kadıların şer'i mahkemeye intikal eden bir davanın kararının tasdikini temin maksadıyla şeyhülislamlığa veya herhangi bir konuda bilgi vermek üzere üst makamlara yazdıkları resmî yazı. Bakınız; Kütükoğlu, a.g.e., 2018, s. 345 .
} 
Arapça'da "sebbe" kelimesi şeteme ile "şeteme" kelimesi de sebbe sözcügü ile açıklanmıştır. Sözlükte bu kelimeler sövmek, yani "terbiye ve nezaketle bağdaşmayan çirkin sözler” anlamına gelmektedir. Sövmenin hukuktaki karş1lığ1 ise, bir kimsenin namus, onur ve kişiliğine yapılan her türlü saldırı anlamına gelmektedir. Allah'ın elçisine doğrudan dil uzatan (söven, küfreden), onun kendisine, ailesine, soyuna, dinine veya ona özgü niteliklerinden birine herhangi bir şekilde ayıp, kusur ve noksanlık katan, dolaylı da olsa ona dil uzatan, kimlik ve kişiliğini diğer bir ifade ile şahsiyetini hafife almak, yaralamak, şan ve şerefini küçük düşürmek, hakaret etmek ve ayıplamak kastıyla birine veya bir şeye benzeten ona sövmüş (sebbetmiş) sayılır (Özarslan 2007: 65-66). Belgede bahsedilen suç ile ilgili olarak, failin itirafı ya da şahitlerin ifadesi gibi kanıta yönelik tahkikatın gizli olarak sürdürülmesi ve Sadaret'e bildirilmesi istenmektedir.

23 Eylül 1311/5 Ekim 1895 tarihinde Edirne Vilayeti'nden Dâhiliye Nezareti'ne çekilen şifre telgrafnamenin suretine göre: Bulgar erbab-1 kaleminden Vazof'un 24 Eylül [1895]'de icrası kararlaştırılan özel gün kutlamaları dâhilinde Monçov (?) isimli birinin programın 9. etkinlik maddesinde Hazret-i Peygamber'e ve Sultan'a sebb (küfür) ettiğine dair bir levhanın teşhir edileceği faaliyetin 19 Eylül [1895] tarihli yarı resmî Mir gazetesinde yayınlanması üzerine, ilgili komiserlikten bilgi verilerek faaliyetin önlenmesi için tedbir alınacağı bildirilmiştir. Dâhiliye Nezareti'ne bildirilen bu olayla ilgili olarak söz konusu gazetede yayınlanan program tercüme edilerek ekte sunulmuştur (Belge-3).

$\mathrm{Bu}$ yazı̧̧madan anlaşıldığ Muhammed hem de İslam halifesi olan Sultan (II. Abdülhamid) birlikte hedef alınmıştır. Bu tür cür'et ve saygısızlıkların çeşitli sosyal etkinlik kisvesi altında programa dâhil edilmesi, İslam üzerindeki itibar düşürücü fazahat girişimlerinin Sultan II. Abdülhamid döneminde yoğunlaştığının örneklerinden biridir. Belgenin ait olduğu dönemin basın-yayın, haberleşme imkânları göz önüne alındığında gazetelerin halkın bilgilendirilmesinde oldukça kritik bir araç olduğunu rahatlıkla söylenebilir. Gazetelerde yayınlanmış herhangi bir haber ya da ilan söz konusu içeriğin yaygınlaştırılması ve alenileştirilmesi anlamına geldiği için basın yayın faaliyetlerinin devlet tarafından denetim ve takibi bugünkünden daha fazla önem taşımaktadır. Özellikle bu tür tahkir ve fazahat girişimlerini normalleştirme çabalarında anılan dönemde gazetelerin yaygınlıkla kullanıldı̆̆ını söylenebilir.

\footnotetext{
3 Ivan Minchov Vazov (1850-1921) Bulgar şair, oyun/roman yazarı ve politikacı.
} 


\section{Ağustos 1312/26 Ağustos 1896 tarihinde Basrulharir ${ }^{4}$ Naibliği tarafin-} dan Mabeyn-i Hümayun Başkitabet-i Celilesi'ne gönderilen telgrafnameye göre: Basrulharir kaymakamı Asım Efendi'nin haşa Hazret-i Peygamber (Muhammed)'e "Adi Adam", Hazret-i İsaya "Veled-i Zina", Hazret-i Musa’ya "Sehhar" gibi ağıza alınmayacak küfür ve sözlerle halkın fikrini tahdiş (incitme) ettiği bildirilerek kaymakamın görevde tutulmasının doğru olmayacağı arz edilmektedir (Belge-4).

İslamiyet, Kur'an-1 Kerim’in buyruk ve içeriği doğrultusunda yalnızca son Peygamber Hz. Muhammed'i değil ondan önceki peygamberleri de kabul ve takdis ederek tümünü İslam dini altında birleştiren bir ilkeyi benimsemiştir. $\mathrm{Bu}$ nedenledir ki telgrafnamede adı geçen diğer peygamberlere -burada adı geçen peygamberler, kimi ilahiyatçıların yorumuna göre ulu'l-azm beş peygamber arasındadır- de hakaret ve küfretmek aynı derecede suç unsuru olarak değerlendirilmektedir. Kaymakamlık düzeyinde devlet görevi yürüten bir kişinin üç semavî dinin peygamberi hakkında onları belgede geçen ithamlarla tahkir etmesi asla kabul edilebilir bir davranış değildir. Ancak bu hakaretlerin arka planında ne tür tezviratların olduğunun araştırılması bu tür suçların kişisel hezeyanlarla sınırlı kalmasını sağlayabilir. Kaymakam Asım Efendi'nin fütursuzca işlediği bu suç karşıllğında görevden azline yönelik suç duyurusu bir başka cezaî müeyyidenin uygulanma şekline örnek teşkil etmektedir.

\section{Muharrem 1318/11 Mayıs 1900 tarihinde Bağdat'ta Erkan-1 Harbi- ye Kaimmakamı (Yarbay) Esad Bey'in Bab-1 Ali'ye gönderdiği tahrirata ${ }^{5}$} göre: Bağdat'ta başıboşluktan şımarmış olan çocukların Muharrem ayının yedinci günü Hz. Aişe'nin paçavradan imal ettikleri timsalini sokaklarda gezdirmeleri, Musa el-Kâzım Cami-i Şerifi'nde bazı İslam halifelerini aşağlamaya cesaret etmelerinin utanç verici olduğu ve müminlerin kalplerinde büyük üzüntü meydana getirdiği arz edilerek gereğinin yapılması için onay istenmektedir (Belge-5).

\footnotetext{
4 Suriye Vilayeti Havran Sancağı'na bağlı Kaza, bakınız; Osmanlı Yer Adları, Hazırlayan: Tahir Sezen, Ankara: T.C. Başbakanlık Devlet Arşivleri Genel Müdürlüğü, 2017, s. 91. Busr'l-harîr veya Busru'lharîr şeklinde de kullanılmaktadır.

5 "Posta ile gönderilen resmî mektup". İstanbul'daki merkez daireleriyle, vilayetler ve dış temsilcilikler ve bunların birbirleri arasındaki yazışmalar (muharrerat) tahrirat adıla anılır. Ancak gerçek anlamda tahrirat denebilmesi için "küçükten büyüğe" yazılmış olması gerekmektedir. Bu bağlamda vilayetlerdeki valilerin nezaretler, sadaret gibi sadece kendilerinden yüksek makamlara yazdıkları yazılar, daha aşağıdaki memurların merkezdeki üstleri, yabancı devletler nezdindeki elçilerin reisülküttab/hariciye nazırı vs.ye gönderdikleri yazılar ile İstanbul dışında bulunanların aralarındaki yazışmalarda muhasebeciden vilayet defterdarına veya defterdardan valiye gönderilen yazılar bu gruptadır. Bakınız; Kütükoğlu, a.g.e., 2018, s. 229.
} 
Hz. Muhammed'in eşi Hz. Aişe'nin ve İslam halifelerinin çeşitli yollarla istihza ve tahkire uğraması da Hz. Muhammed'e ve İslamiyet'e yönelik fazahat girişimleri kapsamında değerlendirilmektedir. Zira, Hz. Peygamber'e beddua eden, lanet okuyan, herhangi bir şekilde zarar görmesini isteyen, kötülemek amaciyla makam, mevkî ve şerefine uygun olmayan şeyleri ona nispet eden, dine (şeriata) aykırı olan yalan sözlerle onu taciz eden, maruz kaldığı bir takım musibet ve zorlukları devamlı bir şekilde anarak onu ayılayan, başkalarında da olabilecek bir takım insanî arızaları bahane ederek onu insanların gözünden düşürmeye çalışan bireyler de ona hakaret ve saygisızlık etmiş olur. Bütün bunlar Hz. Peygamber'e sövme (sebbetme) kavramı içerisinde giren eylem ve davranışlardan sayılmıştır (Özarslan 2007: 66). Bu tür fazahat eylemleri, İslam ümmeti arasındaki bazı görüş ve usul ayrıllğ̆ını çekişmelere dönüştürerek telafisi mümkün olmayan kutuplaşmalara neden olabilmektedir.

\section{Kanun-1 sani 1326/23 Ocak 1911 tarihinde Erzurum Vilayeti'nden Bab-1 Ali Dâhiliye Nezareti Muhaberat-1 Umumiye Dairesi'ne gönderilen şifreli} yazıya $^{6}$ göre: Sığır vebası hastalığının tedavisi için Tercan'a gitmiş olan Baytar Müfettişi Sabit Efendi'nin Ermeni murahhasa vekilinin ikametgâhında kaymakam ve diğer bazı kişilerle birlikte içki içtikleri sırada Peygamber-i zi-şan (Hz. Muhammed) hakkında çirkin sözler söylemeye cüret ettikleri, Hazret-i Meryem'in bir fahişe olduğunu ifade edecek kadar cinnet getirdiklerinin alınan telgraf ile anlaşılmasıyla olay mahallinde tutulan kişiler ile yine orada bulunup sonra oradan kaçan boyacı ve firıncının da derhal der-dest edilerek mahkeme huzuruna çıkarılması gerekliliği bildirilmektedir. Ayrıca Adliye Nezareti'nin de bu konuda gerekli hassasiyeti göstererek süratle harekete geçmesi gerekliliği arz edilmektedir.

\section{Kanun-1 sani 1326/24 Ocak 1911 tarihinde Erzurum Valisi Celal Bey'in} Bab-1 Ali Dâhiliye Nezareti Muhaberat-1 Umumiye Dairesi'ne gönderdiği tahriratta: Vilayet Maarif Müfettişinin yarın harekete geçerek söz konusu olaya sebep olan kişilerin görevlerinden süratle azledileceği bildirilmektedir (Belge-6).

Yazışmadan, hakaret ve küfür hadisesinin içkinin tesiri altında gerçekleştiği ancak tanıklar vasıtasıyla ispatlanması suretiyle davanın görüleceği anlaşı1maktadır. Yine bu belge İslamiyet'in yalnızca Hz. Muhammed'e değil diğer peygamberlere ve onların ailelerine yönelik hakaret ve küfrü de suç kapsamı içinde değerlendirdiğini açıkça ortaya koymaktadır. Ayrıca suçun kabulü ve

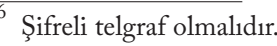


pişmanlık olması durumunda bile görevden azil cezasının uygulanacağı bildirilmektedir. Buradaki pişmanlık beyanı ya da içkinin tesiri hafifletici bir neden olarak değerlendirilebildiği gibi asla mazeret kabul edilmemiştir. Bu belgede yine dikkati çeken bir nokta da olayın bir iftira olup olmadığının kesinlik kazanmasına yönelik çabadır. Bu tür olayların (suçların) ağır cezaları olması hasebiyle böyle durumlarda mutlaka şahitlerin ifadelerine başvurma zorunluluğu adaletin yerine getirilmesinde önemli bir önkoşul olarak karşımıza çıkmaktadır.

Hz. Muhammed'e, ailesine, İslam Halifelerine ve diğer peygamberlere yönelik fazahat girişimleri yalnızca münferit hadiselerle sınırlı kalmamıştır. Yine yoğunlukla II. Abdülhamid döneminde kitap, mecmua, gazete, afiş, broşür, el ilanı gibi çeşitli basılı evrak vasıtasıyla kendini göstermeye devam etmiştir. Arşiv belgelerinden örnekler vermeden önce bu girişimlerin arka planına dair bazı bilgiler vermek yararlı olacaktır.

650-750 yılları arasındaki Hıristiyan kaynaklarda, müelliflerin Arabistan'da bir şekilde ortaya çıkan bu oluşumu (İslamiyet'i) anlama ve yorumlama çabası içine girdiklerini, bu oluşumun ekonomik, askerî, siyasî ve teolojik sebepleri üzerine kafa yorduklarını görmekteyiz. Bu kaynaklarda, Hz. Muhammed'in askeri bir komutan, ticaret adamı, kral, monoteizmi yeniden canlandıran biri, kanun koyucu ve nihayet sahte peygamber olarak adlandırıldığı gözlemlenmektedir. Birçok Müslüman âlim de doğal olarak Hıristiyanlık hakkında çeşitli tarzlarda reddiyeler yazmıs, fakat reddiyeleri yaparken muadillerinin yaptığı şekliyle tahkir ve aşağılama üslubunu benimsememişlerdir (Korkut, 2008: 9-10).

Batı'nın Hz. Muhammed algısı ve tasavvurunda da Bizans döneminde bu alanda üretilen ilk eserlerin önemli, hatta günümüze kadar şekliyle aşılamayan bir payı vardır. Öyle ki bu eserlerin içerikleri ile söz konusu imajın son örnekleri şaşırtıcı şekilde kısmen örtüşmektedir. Örneğin İbrahim Kalın’ın da işaret ettiği gibi VII. yüzyılda Yuhanna ed-Dımişki’nin (ö. 750) Hz. Muhammed'i "sahte peygamber" olarak itham etmesi ile 2002 yilında Amerikalı Evanjelist Jerry Falwell'in Hz. Peygamberi terörist olarak vasıflandırması arasında bir süreklilik vardır (Kalın, 2019: 14). Keza Hz. Peygamberin özellikle özel hayatı üzerinden yapılan hakaretler bu imajın vazgeçilmez sabitelerindendir (Korkut, 2008: 12). Bu tespit, Hz. Muhammed'e yönelik fazahat girişimlerinin sistematik ve sürekli olduğunu ortaya koyması açısından dikkat çekicidir. Konuyla ilgili olarak seçilen aşağıdaki arşiv belgelerinde yer alan ifadeler de, Hz. Muhammed üzerinden İslamiyet'in tüm kutsallarına ve 
onları ayakta tutmaya çalı̧san Türk milletine yönelik fazahat girişimleri tespitlerini maalesef doğrular ve kanıtlar niteliktedir.

b. Kitaplar aracıllğgyla yapılan fazahat eylemlerine örnek teşkil edebilecek belgeler:

\section{Mart 1291/16 Mart 1875 tarihinde Maarif Vekâleti Mektubi Kalemin-} den Bab-1 Ali'ye gönderilmek üzere hazırlanan müsveddede: Meclis-i Maarif'e gönderilen bir kitabın içeriğinde enbiya-i izam hazeratının risaletlerine uygun olmayan söz ve çarpıtmalar görüldüğü ve bunların düzeltilmesinin mümkün olmayacağı tespiti üzerine bu kitabın Osmanlı Devleti'nde yayınlanmasının caiz olmayacağı arz edilmektedir (Belge-7).

$\mathrm{Bu}$ belgede söz konusu kitapta Hz. Peygamber hakkında verilen bilgilerin doğruluğunun ve üslubunun denetimi yapılarak düzeltilmesinin de işe yaramayacağı vurgulanmış, uygun görülmemesi sonucu kitabın Osmanlı Devleti sınırları içinde yayınlanamayacağı konusu Bab-1 Ali'ye arz edilmiştir.

\section{Mart 1310/25 Mart 1894 tarihinde Zabtiye Nezareti'nden kaleme al1-} nan müzekkireye ${ }^{7}$ göre: Kadıköy'de Frer $^{8}$ ismindeki Fransız mektebi talebesine, içeriğinde Fahr-i Kainat Efendimiz hazretleri İslam dini ve Müslümanlar aleyhinde ve hakikat hilafinda ibareler, makalelerin de bulunduğu "La Trailösze” adlı Coğrafya kitabının okutulduğu haber alınmıştır. Bu kitabın bir adedi Maarif Nezareti Matbaası Müfettişi Vaporidi Efendi aracılığıyla temin edilmiştir. Kitabın ilgili yerleri tercüme edilerek ekte sunulmuştur (Belge-8/1-8/2).

\section{EK (LEFF)}

\begin{tabular}{|l|l|}
\hline Sayfa & Tercüme \\
\hline 93-99 & $\begin{array}{l}\text { Beyaz cinsinden olan Asya kavimleri din-i İlam nüfuzuyla vahşiliğe } \\
\text { saptılar }\end{array}$ \\
\hline 140-147 & $\begin{array}{l}\text { Muhammed Medine'ye firar ile Hiristiyanlık ve Yahudilik ve } \\
\text { putperestlikten mürekkeb din-i İslam' vaz eyledi }\end{array}$ \\
\hline
\end{tabular}

\footnotetext{
Herhangi bir husus için alttan üste ve genellikle aynı şehir veya dairedeki bir idare veya nezaretin şubelerinden bağlı olduğu üst makama hitaben konuyla ilgili izin istemek yahut bir şubeden diğer bir şubeye durumu anlatmak veya muameleyi sormak üzere yazılan elkabsız yazılardır. Bakınız; Kütükoğlu, a.g.e., 2018, s. .

8 1870'de Frères des Ecole Chrètiennes'e bağlı olarak açılan günümüzde Özel Saint Joseph Fransız Lisesi. Bakınız; Ekrem Aksoy, "Başlangıcından Günümüze Türkiye'de Fransız Okulları”. Synergies Turquie (8, 2015): 29-46.
} 


\begin{tabular}{|c|c|}
\hline $142-147-148$ & $\begin{array}{l}\text { Asya kıtası din-i İslamin şebvet ve fesad-amiz nüfuzuyla kâmilen } \\
\text { inkıraz buldu }\end{array}$ \\
\hline $148-154$ & $\begin{array}{l}\text { Islamın uğursuz ve muballil tarıi ve dini vaktiyle abadan olan } \\
\text { birtakım memaliki harab ve ahalisini mahveyledi }\end{array}$ \\
\hline 192-201 & $\begin{array}{l}\text { Din-i İlamı bina eden kazib Muhammed kendi mutaassıb } \\
\text { arkadaşların dünyanın fethine serk eyledi }\end{array}$ \\
\hline 196-202 & $\begin{array}{l}\text { Mekke'nin nüfuz-ı tahammüllerini dünyanın tarafina yayan kullara } \\
\text { illetini tabrik eder }\end{array}$ \\
\hline 198-207 & $\begin{array}{l}\text { Türkiye Devleti bugünkü gün çürümekte olup İngiltere’nin bimayesiyle } \\
\text { Rusya'nın hücumuna karşı durabiliyor }\end{array}$ \\
\hline 200-209 & $\begin{array}{l}\text { Yarım putperest ve vahşi Dürzîler ki } 1860 \text { taribinde Hiristiyanlar } \\
\text { katleylediler Maronitlerin düsmanlarıdır }\end{array}$ \\
\hline 201-211 & $\begin{array}{l}\text { Islamdan harap olan bi'l-cümle memalikin olduğu gibi Asya kıtasının } \\
\text { sarf ve sanayii mabrolmuștur }\end{array}$ \\
\hline 204-213 & $\begin{array}{l}\text { Rusya ve Yunan ve Türklerin din azizleri Beytüş-Şam'daki Katolikleri } \\
\text { iğfal ediyor }\end{array}$ \\
\hline $25-238$ & $\begin{array}{l}\text { Türkiye memaliki yağma olursa Trablusgarp ciheti Italyanlar'a } \\
\text { münasipgelecek }\end{array}$ \\
\hline 458-459-489 & Din-i İlam gazabını Avrupa'ya sevk eylediö́i esnada... \\
\hline & 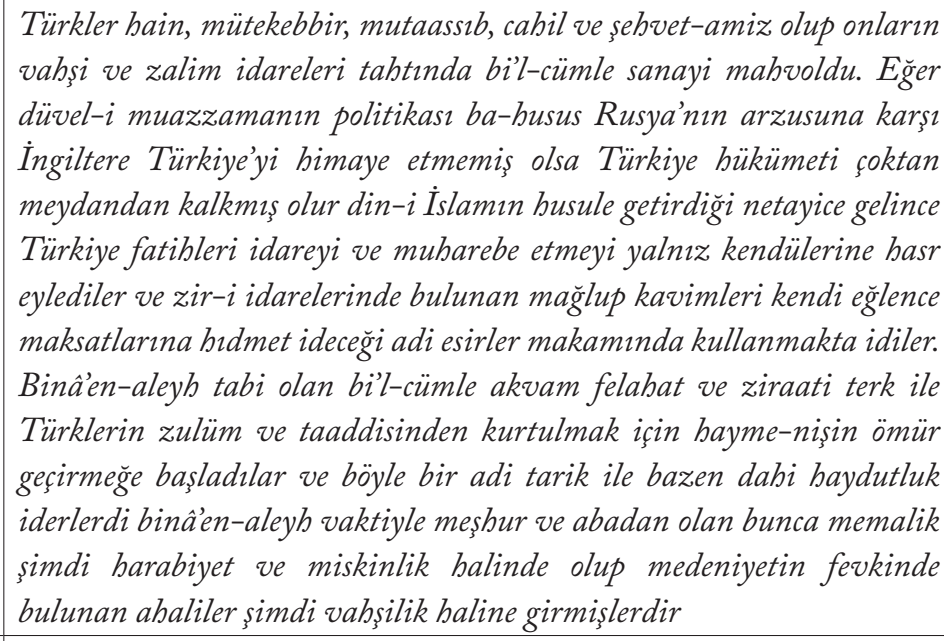 \\
\hline $581-646$ & $\begin{array}{l}\text { Türklerin kayıtsızliğı bu harabelerde birtakım hastalıklar tevellüd } \\
\text { eylemesine muceb oluyor. }\end{array}$ \\
\hline 583-643 & Avrupa'nın en arkada kalmıs olan sanayisi Türklerin sanayiidir \\
\hline
\end{tabular}


Söz konusu kitabın içeriğinden tespit edilen ifadeler dikkatle incelendiğinde Türk İslam medeniyetine ağır itham ve hakaretlerin yapıldığ 1 rahatlıkla anlaşılmaktadır. Herhangi bir tevil ya da yoruma gerek duyulmaksızın kitabın birçok yerinde hem millî hem de dinî birçok değerimize açıkça saldırılması o dönemdeki kin ve düşmanlığın yanı sıra cüretin ulaştığı noktayı da göstermektedir.

\section{Teşrin-i sani 1310/19 Kasım 1894 tarihinde Beyrut Maarif Müdürü Mahmud Celaleddin Bey tarafindan Maarif-i Umumiye Nezaret-i Celile-i} Saniyesi'ne gönderilen müzekkireye göre: Londra'da basılan "Muhammed ve Din-i Muhammed̂̂” isimli risaleye gümrükte tarafimca el konulmuştur. Risalenin anlaşılması için tarafsız olarak hazırlanan tercümesini ekte takdim ederek söz konusu risalenin kesinlikle ve bütünüyle yayınlanmasının reddedilmesi gerekliliğini arz ederim.

\section{Teşrin-i sani 1310/1 Aralık 1894 tarihinde Beyrut Maarif Müdü-} rü Mahmud Celaleddin Bey tarafindan Maarif-i Umumiye Nezaret-i Celilesi'ne gönderilen müzekkireye göre: İngilizce olarak yayınlanan bu risalenin 112. sayfasındaki din-i Muhammedî hakkındaki bilgiler dinî kuralları tenkit eder içeriktedir. Bu nedenle bu risaleye el koyduğumu bildirerek ekte takdim ederim.

13 Şubat 1310/25 Şubat 1895 tarihinde Maarif-i Umumiye Nezareti Mektubi Kalemi'nden Dâhiliye ve Zabtiye Nezareti Celileriyle Rüsumat Emanet-i Celilesi'ne ve Telgraf Nezaret-i Aliyyesi'ne gönderilen şukkaya9 (müsveddedir) göre: S. Dokoil'in Londra'da tab’ ettirdiği İngilizce "Muhammed ve Muhammediyet" isimli kitap ${ }^{10}$ ile Markus Dövos isimli yazarın yine İngilizce olarak Londra'da basılan "Muhammed ve Buda ve İsa"11 serlevhalı (başlıklı/ eser adlı) kitabı İslam aleyhinde olduğu için Beyrut Maarif Müdüriyeti’nden gönderilmiştir. Bu kitaplar incelendikten sonra İslamiyet aleyhinde asla kabulü mümkün olmayan içerikte oldukları anlaşılmıs, söz konusu kitapların

\footnotetext{
Merkezle taşra veya taşradaki iki yer arasındaki ve üstten alta yapılan yazışma türüdür. Bakınız; Kütükoğlu, a.g.e., 2018, s. 233.

${ }^{10}$ Belgede adı geçen kitap İngiliz yazar Reginald Bosworth Smith (1839-1908)'in 1874 ve 1876 'da Londra'da Smith, Elder \& Co. tarafindan basilan Mohammed and Mohammedanism: Lectures Delivered at the Royal Institution Great Britain in February and March 1874 adlı kitabıdır. Kitap, 1875'te New York'da Harper \& Brothers (2. baskı) ve 1889 'da yine Londra'da John Murray Yayinevi tarafindan (gözden geçirilmiş ve genişletilmiş 3. baskı) tekrar basılmıştır. Ancak belgede geçen "S. Dokoil" ibaresi büyük olasılıkla ilk ve 1876'daki basımı yapan Smith, Elder \& Co. yayınevini çăgrıştırmaktadır.

${ }^{11}$ Belgede adı geçen kitap, İskoç papaz ve ilahiyatçı Marcus Dods (1834-1909)'un 1877'de Londra'da Hodder and Stoughton tarafindan basilan Mubammad, Buddha and Christ: Four Lectures on Natural and Revealed Religion adlı kitabıdır.
} 
Memalik-i Mahruse-i Şahanede yasaklanması gereği maarif müdürlerine bildirilmiş, aynı uyarı gümrüklere de gönderilmiştir (Belge-9/1-9/2-9/3).

Bu üç belge; İslami değerler, Hz. Muhammed ve Türk milleti aleyhindeki gerçek dişı çarpıtmaların ders kitapları aracılığıyla yayılmasının sağlanarak gençlerin ve çocukların hedef alındığını açıkça göstermektedir. Bu girişimler o dönem için ilk ve yeni olmamakla beraber bir zincirin halkası şeklinde ilerlediğini anlamak için önceki faaliyetlere ve onların içerik/amaçlarına değinmek gerekmektedir.

Hıristiyanlar tarafindan İslam'a karşı reddiye türünde yazılmış ilk eser $\mathrm{He}-$ lenistik dönem sonu Kilise babası olarak anılan Yuhanna ed-Dımişki'nin kaleme aldığ 1 "De Haeresibus (Sapkınlar)" adlı kitaptır. Müellif, Kur'an'ın Hz. Muhammed tarafindan üretildiğini savunarak öncelikle onu "yalanc1 peygamber", “ikiyüzlü” ve "şehvetperest” olarak vasıflandırmıştır. Bunun yanı sira Theophanes the Confessor'un "Chronographia" $1^{12}$, Bizansli Nicetas Byzantios'un "Refutatio Mohammedis" ${ }^{13}$ ve yazarı bilinmeyen "Apology" adlı eserde genel olarak Hz. Muhammed'in sahte peygamber ve çok evlilik yaptığ için dünyevi zevklere düşkün olduğu öne sürülmektedir (Korkut, 2008: 12).

Belgede incelenen Fransızca coğrafya kitabındaki itham ve iftiraların kökeninin de Hz. Muhammed'e yönelik fazahatın boyutlarının anlaşılması açısından bu eserler oldukça dikkat çekicidir.

Ayrıca bu eserlerin bazıları telif edildikten kısa bir süre sonra kısmen veya tamamen Latice'ye çevrilmiş, ayrıca benzer türdeki eserlerle literatür genişlemeye başlamıştır. Böylece Batı'da Hz. Muhammed ve İslam algısı şifahi ve yazılı olarak asırlarca geniş halk kitlelerinde yaygınlaştırılmıştır (Korkut, 2008: 12-13).

Ortaçağda yazılmış olan Hz. Muhammed hakkında gayet küçültücü ifadelerin yer aldığı "Chanson de Geste" gibi destanlar ise, bugün bazı Avrupa ülkelerinde milli dillerinin ilk örnekleri olması bakımından dil ve edebiyat derslerinde örnek metinler olarak okutulmaktadır (Karlığa, 2004: 15-16). Batı'da ilk ansiklopedi olarak kabul edilen Bibliotheque Orientale de D'Herbelot'un Hz. Muhammed'i meşhur düzenbaz ve yalancı peygamber olarak nitelen-

\footnotetext{
${ }^{12}$ Bizanslı keşiş ve vakanüvis Theofanis (758-817)'in 284-813 yılları arasını kapsayan Roma-Bizans tarihi kitabıdır.

${ }^{13}$ Bizanslı Niketas'ın (9. yüzyıl) bazı kaynaklarda Confutatio Alcorani olarak da geçen kitabı. Bakınız; Hilal Görgün, "Muhammed", TDV İslam Ansiklopedisi c.30 içinde (476-478), İstanbul: TDV, 2005.
} 
dirdiği görülmektedir. Ayrıca bu dönemde yazılan Fransızca sözlüklerde "sahtekâr" kelimesi tarif edildikten sonra örnek olarak Hz. Muhammed verilmiştir. Sözlük (Dictionnaire Universel) ${ }^{14}$ yazarı Antoine Furetière "imposteur" maddesinde bunu yapmaktadır. XVII. ve XVIII. yüzyılda yazılan bazı Protestan kitapları ve Arapçadan çevrilen siyer kitaplarında bir yandan Hz. Muhammed'e olumlu bir şekilde bakılması sağlansa da bir yandan da bu tür eserlere rağbet etmeden olumsuz imaj üreten faaliyetler sürüp gitmiştir (Korkut, 2008: 20, 23).

c. Gazete ve dergiler aracıllğıyla yapılan fazahat eylemlerine örnek teşkil edebilecek belgeler:

\section{Temmuz 1309/31 Temmuz 1893 tarihinde Zabtiye Nazırı Hüseyin Na-} zım Paşa imzasıyla Bab-1 Ali'ye gönderilen takrire ${ }^{15}$ göre: Paris'te yayınlanan "[La] Gadriyol"16 isimli Fransiz gazetesinin 30 Temmuz 1893 tarihli ve 243 numaralı nüshasında fahr-1 kâinat efendimiz hazretlerinin cenneti serlevhasiyla bir resim ve bunun yanı sıra İslamiyet aleyhinde bir de makale bulunduğu tespit edilmiştir. Bu tür tasvirlerin ve yayınların payıtahta girişi ve yayılmasının caiz olmadığı düşüncesiyle söz konusu nüshaların toplattırılması Beyoğlu mutasarrıflığına bildirilmiş, sadrazam hazretleri bu konuda bilgilendirilmiş ve adı geçen gazetenin malum nüshası ekte arz ve takdim k1lınmıştır (Belge-10).

\section{Bab-1 Ali Nezaret-i Umur-1 Hariciye Tercüme Odası'nın 13 Teşrin-i evvel} 1309 / 25 Ekim 1893 tarihli tahriratta; Bab-1 Ali Nezaret-i Umur-1 Hariciye Tercüme Odası Hariciye Nezareti'ne 25 Teşrin-i evvel (12)93/7 Kasım 1877 tarihli 478 numaralı Londra Sefareti’nden gönderilen yazının tercümesine göre: El yazısı ile yazılmı̧̧ bazı mühim evrakın ortaya çıkarıldığına dair İngiliz gazeteleri tarafindan yayınlanan fikra (köşe yazısı), nezaret penahilerinin telakki ve mülahazalarına ehemmiyetle sunulmaktadır. Bu yazısmanın ekinde söz konusu gazetede yayınlanan yazının tercümesi bulunmaktadır. Ekte sunulan tercümede: Padişah hazretlerinin 5000 Liraya Mösyö "Barbiyan" isimli bir Fransız'dan el yazısı ile yazılmış iki varaka satın aldığı ve bunların

\footnotetext{
${ }^{14}$ Fransız bilim adamı, yazar ve leksikograf Antione Furetière (1619-1688)'in ilk bakıs1 1690'da La Haye ve Amsterdam'da Arnaout \& Reinier Leers tarafindan yapilan ve tam ad Dictionnaire Universel Contenant Generalement tous des mots François tans veiux que Modernes, et les Termes de Toutes les Sciences et des Arts olan sözlüğüdür. Bakınız; https://gallica.bnf.fr/ark:/12148/bpt6k3413126b/f15.image

${ }^{15}$ Bir işi yazılı olarak ilgili merciye bildiren elkabsız resmî belge. Bakınız; Kütükoğlu, a.g.e., 2018, s. 214.

${ }^{16}$ La Gaudriole: Journal de Joyeux Récits, Chansons, Contes Gaulois et Romans Illustrés, 1891-1905 aras1 Paris'te Pazar ve Perşembe günleri yayınlanan Fransızca resimli/karikatürlü gazete.
} 
Hz. Muhammed'e atfolunan iki mektup olduğu rivayet edilmektedir. Ayrica bu mektupların doğruluğu yani Hz. Muhammed'e ait olduğu İslam uleması tarafından tasdik edilmiştir. Rivayete göre bu mektuplar alem-i İslamiyeyi altüst edecek içeriktedir (Belge-11).

\section{Kanun-1 sani 1310/26 Ocak 1895 tarihinde Bab-1 Ali'ye gönderilen} Şehremini Rıdvan Paşa ${ }^{17}$ imzalı takrire göre: Hz. Peygamber ile diğer büyük peygamberler ve tanınmış bazı din âlimlerinin tasvirlerini içeren evrak derdest edilerek ekte sunulmuştur. Bu tür evrakın gazino gibi uygunsuz yerlere asılmasına zabıta tarafından müdahale edilmiştir, bu tür olayların yaşanmaması için Rüsumat Emaneti’nin gümrükte geçişler sırasında gerekli tedbirleri alması önemle vurgulanmaktadır (Belge-12).

Hz. Muhammed'in tasvirlerinin yapılması fahr-1 kâinat efendimizi sıradanlaştırma çabalarının bir tezahürüdür. Üstelik bu sözde tasvirlerin uygunsuz yerlere asılması fazahat girişiminin bir başka çirkin yüzü olarak karşımıza çıkmaktadır. Hz. Muhammed'in ulvi şahsiyetinin ve hayatının basit hikâye ve tasvirler eşliğinde sunulması, İngiliz gazetelerinde Peygambere atfedilen mektupların içeriğine dair asılsız ithamların yayınlanması, Osmanlı Devleti’nin her alanda çökertilmeye çalışıldığı bu dönemde İslam Halifesi'nin müdahale etmek durumunda kaldığı girişimler olarak da yorumlanabilir.

\section{Nisan 1338/10 Nisan 1922 tarihinde Mabeyn-i Hümayun-1 Mülükane Başkitabeti'nden kaleme alınıp Adliye Nezareti ve Meşihata tebliğ olu-} nan takrire ${ }^{18}$ göre: İslami hükümlere göre kabul edilmesi mümkün olamayan Babî mezhebini cahil insanlara telkin etme, anlatma ve memalik-i şahanede yayılması maksadıyla "İctihad"19 ismindeki mecmuada mürted kişiler tarafindan yazılan ve içeriğinde peygamber efendimize zarar veren sözler bulunan makalenin neşriyatı karşısında devlet dairelerinin sessiz kalması padişah hazretleri tarafından teessürle ve teessüfle karşılanmıştır. Babî mezhebinin dini esaslarımızla hiçbir münasebeti olmadığından bu mezhebin yayılmasının şer'an caiz olmayacağ 1 için ümmet-i Muhammedî rencide edecek bu tür zararlı/müfteri neşriyatın takibi ve önlenmesi doğrultusunda kanuni yapt1rımların uygulanmasının ilgili kurumlara bildirilmesi emredilmektedir (Belge-13).

\footnotetext{
17 (1856-1906), 1890-1906 yılları arasında İstanbul Belediye başkanlığı yapmış devlet adamı.

${ }^{18}$ Bir işi yazılı olarak ilgili merciye bildiren belge türü. Bakınız; Kütükoğlu, a.g.e., 2018, s. 214.

${ }^{19}$ Eylül 1904-1932 yılları arasında çeşitli çıkış sıklıklarıyla Cenevre, Kahire ve İstanbul'da yayımlanan, 1909-1911, 1915-1918 ve 1919-1921 yılları arası kapalı kalan dergi. Bakınız; Nazım H. Polat, "İctihad”, TDV Íslam Ansiklopedisi c. 21 içinde (446-448), İstanbul: TDV, 2000.
} 
Belgeden anlaşıldığına göre, Hz. Muhammed'e yönelik fazahat girişimlerinin kaynağı yalnızca İslam dışı değildir. İslami hükümleri farklı ve dinin özünden uzak yorumlayan birtakım mezhepler de İslamiyet ile $\mathrm{Hz}$. Muhammed'in bağını koparmak amacına yönelik girişimlerde bulunmaya devam etmişlerdir.

Hz. Muhammed'e yönelik itham, iftira ve saygısızliklar yalnızca basın-yayın aracılığıyla sınırlı kalmamıştır. Yukarıda bahsedilen yayınlar ve yayın girişimleri ile oluşturulmak istenen İslam ve Hz. Muhammed algisı mitolojik unsurlarla da süslenerek resim, müzik, tiyatro, dram, piyes ve sinema gibi etkinliklere de yansımıştır.

Voltaire 1742 y1lında "Fanatisme ou, Mahomet le Prophete" adlı bir tiyatro yazmış, bu eserde Hz. Muhammed'i insanların ruhunu tutsak eden bir hilekâr olarak sunmuştur (Korkut, 2008: 28). 1890 yılında Fransız tiyatro yazarı Marki dö Bonnier, Hz. Muhammed'in manevî şahsiyetini küçük düşürücü nitelikte "Muhammed"20 adlı bir dram (piyes) yazmış ve sahnelenmesi için metni Commedie Français'e teslim etmiştir. Oyunun sahneleneceğine yönelik haberler Avrupa gazetelerinde yer almış, Bunun üzerine Sultan II. Abdülhamit Paris sefiri Salih Münir Paşa vasıtasıyla Fransa Cumhurbaşkanı Sadi Carnot'a ${ }^{21}$ haber göndererek oyunun sahnelenmesini engellemiştir. II. Abdülhamid bürokratik müdahaleleriyle ABD ve İngiltere'de sergilenmeye çalışılan aynı oyun ve benzer yapıtları engellemiş, sahneden kaldırtmıştır (Korkut, 2008: 40). Bu örnekleri aşağıdaki belgelerle çoğaltmak ve kanıtlamak mümkündür.

d. Tiyatro, oyun, piyes aracılı̆̆ıyla yapılan fazabat eylemlerine örnek teşkil edebilecek belgeler:

\section{Temmuz 1306/21 Temmuz 1890 tarihinde Hariciye Nazır1 [Said Halim} Paşa $]^{22}$ tarafından Sadaret'e gönderilen tezkire-i aliyyeye ${ }^{23}$ göre: Paris ve Londra'da bazı kişiler namına gönderilen risalenin daha önce "Hz. Muham-

\footnotetext{
${ }^{20}$ Fransız şair ve drama yazarı Vicomte Henri de Bornier (1825-1901)'in 1888-1889'da tamamladığı "Mahomet" adlı dram. de Bornier bu piyesi, 1889'da Fransiz Devlet Tiyatrosu olan Comédie Française'de teslim etmiş ardından gazetelerde sahneleneceği ilan edilmiştir. Paris sefiri Mahmud Esad Paşa'nın yoğun diplomatik girişimleri ile sahnelenmesi engellenmiştir. Bakınız; C. E. Bosworth, "A Dramatisation of the Prophet Mohammed's Life: Henri de Bornier's "Mahomet". Numen 17 (2, August): 105-117, 1970; Cengiz Kallek, "Henri de Bornier (1825-1901)". TDV İslam Ansiklopedisi c. 6 içinde (292-293), İstanbul: TDV, 1992; Mahmut Akpınar, "Osmanlı Hariciyesi’nde Yaklaşık Kırk Yı1: Mahmud Esad Paşa (1837-1895)”. FSM İlmî Araştırmalar Dergisi (5, Bahar): 29-51, 2015.

${ }^{21}$ Marie François Sadi Carnot (1837-1894).

22 (1864-1921), 1912-1917 yılları arasında sırasıyla Şura-yı Devlet Reisliği, Hariciye Nazırlığı ve Sadrazamlık yapmış devlet adamı.

${ }^{23}$ (Tezkire) Aynı beldedeki resmi daireler veya şahıslar arasındaki haberleşmeleri temin eden belge, (tezkire-i aliyye) şeyhülislam ve nazırlar tarafından yazılan tezkirelere verilen ad. Bakınız; Kütükoğlu, a.g.e., ss. $245-250,2018$.
} 
med" adlı bir piyes olarak Paris'te sahnelenmesine engel olunmuştur. Bu defa Londra'da sahnelenmek istenmektedir. Londra'da sefaret tarafindan yapilan tahkikatta piyese kaynaklık eden risalenin Osman Melencin tarafindan yazıldığı, "el-Cevâib" gazetesinin eski sahibi Selim Fâris'in ${ }^{24}$ da Londra'da bulunduğu sırada risalenin yayınlanması işinde olabileceği tespitleri üzerinde değerlendirmeler yapılmaktadır. Bunun yanı sıra İslam’ın şiarına aykırı bu zararlı risalenin İngiltere'de yayınlanmasının matbuat serbestliğinden dolayı yasaklanmayacağı, ancak piyesin sahneye konulmasının engelleneceği bildirilmektedir (Belge-14).

\section{Teşrin-i evvel 1306/24 Ekim 1890 tarihinde Londra sefaretinden Rüs-} tem Paşa ${ }^{25}$ tarafından Bab-1 Ali'ye gönderilen tahriratta: Hz. Peygamber'in temsiliyle Londra ve Paris'te icra olunacak tiyatro oyunun padişahın girişimleri sonucunda yasaklanmasından dolayı, Liverpool'daki Cemiyet-i İslamiye ikinci başkanı Hint asıllı Refiyüddin Sac'ın teşekkür ve minnettarlı̆̆ını içeren tercümenin ekte takdim kılındığı belirtilmektedir. Ekte sunulan teşekkür tercümesinde hem padişaha minnet ve teşekkür hem de Avrupa ve Amerika'da İslamiyet'i yayma çalışmalarının devam ettiği bildirilmiştir (Belge-15).

\section{Teşrin-i sani 1308/29 Kasım 1892 tarihinde Nezaret-i Maarif-i Umu-} miye Encümen-i Teftiş ve Muayene kaleminden yazılan takrire göre: Bir nüshası der-dest olunan "Mahumet" isimli Fransız tiyatro risalesi isminden de anlaşılacağı üzere fahr-1 kâinat efendimiz hakkındadır. Daha önce Paris'te sahneye konulduğunda fevkalade zararları sebebiyle bu eserin yasaklandığı da bilinmektedir. Bu eserin kütüb-i muzırra cetveline (listesine) dâhil edilmiş ve memalik-i Osmaniye'ye girişinin yasaklanması için Rüsumat Emanet-i Celilesi’ne ve maarif müdürlerine bilgi verilmiştir. Söz konusu risale ekte arz ve takdim kılınmıştır.

\section{Teşrin-i sani 1308/1 Aralık 1892 tarihinde Mektubi Kalemi'ne yazı-} lan takrirde ise: Evvel emirde mevcut nüshaların zabıta usulü ve müfettişler marifetiyle toplattırılması elzemdir. Toplattırılan nüshaların yakılarak imha edilmesi buyurulmuştur (Belge-16).

\footnotetext{
${ }^{24}$ Selim Fâris ve tiyatro sorunu için ayrıca bakınız; İbrahim Şirin, "Gazete, Kitap, Tiyatro Karşısında İmajını Korumaya Çalışan Sultan ve Maiyeti: Sultan II. Abdülhamid ve Ahmed Mermi”. Cyprus International University Folklor / Edebiyat Dergisi 17 (66): 39-55, 2011.

${ }^{25}$ Rüstem Paşa (1814/15-1895), 1885-1895 yılları arasında Londra Büyükelçiliği yapmış bürokrat, diplomat ve devlet adamı.
} 


\section{Temmuz 1893 tarihinde Washington Sefiri Alexander Mavroyeni ${ }^{26}$} Bab-Ali'ye gönderdiği takrirde: Amerika tiyatrolarında Hz. Peygamber namına bir lubbiyatın (eğlence, tiyatro) icra edileceğine dair duyum alınması üzerine oyunun sahneleneceği yere bizzat giderek tahkikat yapacağını ve durumu padişah hazretlerine arz edeceğini bildirmektedir (Belge-17).

\section{Temmuz 1309/19 Kasım 1893 tarihinde Hariciye Nazırı [Said Halim Paşa] tarafindan Bab-1 Ali'ye gönderilen ve ekinde Londra Sefareti'nden alınan 500 numaralı takrir tercümesinin bulunduğu tezkire-i aliyyeye} göre: Londra tiyatrolarından birinde "Hz. Muhammed” serlevhalı bir dramın sahneye konulacağına dair rivayet hakkında baş mabeynciden alınan bilgiye göre böyle bir oyun hakkında 1890 senesinden beri yeni bir şey işitilmediği, İngiltere devletinin Müslümanların dini hayatına dokunabilecek her türlü girişimden çekindikleri, eğer bu konuda bir izin talebi olursa asla kabul edilmeyeceği bildirilmektedir. Bu yazı 20 Kasım 1890 tarihinde Sadrazam Ahmed Cevad Paşa tarafından bu konuda gerekli tedbirlerin alındığı bilgisiyle Bab-1 Ali'ye ekiyle beraber arz ve takdim kılınmıştır (Belge-18).

Bu belgeler II. Abdülhamid döneminde İngiltere, Fransa ve Amerika Birleşik Devletleri'nde dram, piyes ve tiyatro adı altında Hz. Muhammed'in konu edildiği bir dizi etkinliğin sahnelenme cüretini ve buna karşılık olarak Osmanlı Devleti'nin ilgili sefaret, cemiyet ve nezaretlerle yazışmalar gerçekleştirerek bu girişimleri önleyebildiğini ortaya koymaktadır.

\section{Temmuz 1339/10 Temmuz 1923 tarihinde Ödemiş Kaymakamı tara-} findan Diyanet İşleri Başkanlığı'na gönderilen yazıda: Ceza Kanunu'nun 99. maddesinin 3. zeyli uyarınca uyulması gereken maddeler hakkındaki 28 Şubat 1337/28 Şubat 1921 tarihli Kararnamenin 4. maddesinde Memalik-i Osmaniye'de tanınmış olan dinler ve mezhepleri tezyif ve tahkir eden ve adab ve ahlak-1 umumiyeye muhalif muzır şeylerin gösterime konulması, ayrıca 5. maddesinde halkın galeyanını harekete geçirecek cüretin yasaklandığı belirtilmektedir. Bu kanuni dayanaklar çerçevesinde enbiya-i izam hazeratına ait menakıb ve ahval-i tarihiyyenin bazı mahallerdeki sinemalarda teşhir edildiği ve gösterime girdiği, bu durumun Müslümanlar arasında galeyana sebep olacağı bu konuda kanuni takibat ile gerekli tedbirlerin alınması gerekliliği bildirilmektedir (Belge-19).

\footnotetext{
${ }^{26}$ Alexander Mavroyeni Efendi (1848-1929), 1887-1896 yılları arası Washington sefirliği, 1902-1904 arası Sisam Valiliği ve 1911-1912 arası Viyana sefirliği yapan Osmanlı diplomatı.
} 
Türkiye Cumhuriyeti'nin kurulma aşamasında üretilen bu belgede bahsi geçen Kararname'nin 4. maddesi Osmanlı Devleti'nde tanınan tüm dinlerin kutsallarına yönelik ahlaksız ve saygısızlı̆̆ açıkça yasaklamıştır. Bu bağlamda Osmanlı Devleti'nin ve devamı olan Türkiye Cumhuriyeti'nin dinlerin kutsiyetine bakış açısında bir çifte standart olmadığını açıkça göstermektedir.

e. Diğer basılı evrak ve nesneler aracılı̆̆ıyla yapılan fazahat eylemlerine örnek teşkil edebilecek belgeler:

25 Kanun-1 evvel 1307/6 Ocak 1892 tarihinde Dâhiliye Nezareti Mektubi Kalemi'ne gönderilen -büyük olasılıkla- müzekkire müsveddesine (?) göre: Avrupa'dan getirilerek Galata gümrügüne çıkarılan bir büyük biri küçük iki adet sedef kakmalı iskemlenin ortasında tuğra şeklinde "lafza-i celal" ve "nam-1 celil-i nebi” nakışı bulunduğu gümrük nezaretine bildirilmiş, bu nakışların adı geçen esmanın şanına aykırı olarak nakşedilmiş olduğundan saygısızlık teşkil edeceği düşüncesiyle söz konusu eşyaların süratle iadesi istenmiştir (Belge-20).

\section{Teşrin-i sani 1309/9 Aralık 1893 tarihinde Bab-1 Ali Daire-i Harici-} ye Mektubi Kalemi'nden Sadaret'e gönderilen Hariciye Nazırı Said Halim Paşa imzalı tezkire-i aliyyede: [Le] Figaro ${ }^{27}$ gazetesinin geçen Teşrin-i sani'nin 29'una ait nüshasında "Monako" isimli bir çerçi tarafindan ilhamlı resim içeren bir levha satılmakta olduğunun görülmesi üzerine Paris Sefaret-i Seniyyesi'nden alınan bildirime cevaben bu resmin meleklerden birinin bir Aziz’ i gökyüzüne çıkardığını tasvir ettiği, sanatça değersiz olan bu resmin kolay müşteri bulabilmesi için bu resme nasıl bir isim verildiği telgrafnamenin tercümesi ekte (aşağıda) sunulmaktadır.

Osmanlı Devleti son dönemlerinde bile İslam'ın mukaddesatını zedeleyeceğini düşündüğü her tür faaliyeti engellemek için tüm nezaretleriyle sıkı bir çalışma yürütmüştür. Bunlardan biri ve belki de en önemlisi yurtdışına ülkeye sokulmak istenen her tür eşyanın kontrolünü yapan gümrüklerdir.

28 Teşrin-i sani 1309/10 Aralık 1893 tarihli telgrafname tercümesi: Mevzubahis olan resim meleklerden birinin kim olduğu bilinmeyen bir Aziz’i gökyüzüne çıkardığını tasvir etmektedir. Adi bir madrabaz olan sahibi sanatça hiçbir değeri olmayan bu resme değer katmak ve kolaylıkla müşteri bulabilmek için bu resme $H z$. Mubammed'in Sema'ya Ref'i adını vermiştir (Belge-21/1-21/2-21/3).

\footnotetext{
${ }^{27}$ Le Figaro, 1826'dan beri yayınlanan Fransız günlük gazete.
} 
$\mathrm{Bu}$ yazışma, yapmış olduğu resmi farklı ve değerli kılmak için $\mathrm{Hz}$. Muhammed'in ismini kullanıp miraç hadisesini çağrıştırma cüretinin gösterildiği münferit girişimlerin bile sefaret aracilığıly takip edilip önlenmeye çalışıldığına dair önemli bir belgedir. 


\section{SONUÇ}

Osmanlı Devleti'nin son dönemine ilişkin konu kapsamındaki arşiv belgeleri, Hz. Muhammed üzerinden İslamiyet'e ve Türkler'e yönelik fazahat girişimlerinin yöntem ve boyutları hakkında fikir vermektedir. Bunun yanı sıra fazahat ile tarif edilen bu girişimlerin ciddi bir bürokratik takip ile engellendiğini görmek, ayrıca "Büyük Devlet Olma" kavramının ne anlama geldiği noktasında da farkındalık oluşturabilir. Büyük çoğunluğu II. Abdülhamid dönemine ait yazışmalardan oluşan çalı̧̧ma kapsamındaki arşiv belgeleri, ait olduğu döneme ilişkin Osmanlı Devleti'nin sınırları içinde ve dışında yoğun bir diplomatik mücadele verdiğini anlayabilmemiz açısından da değerlendirilebilir. Yazı̧̧maların yapıldığı Meclis-i Vala, Sadaret, Bab-1 Ali, Adliye Nezareti, Dâhiliye Nezareti, Hariciye Nezareti, Maarif Nezareti, Zabtiye Nezareti, Bab-1 Meşihat, Diyanet İşleri Reisliği ve Sefaretler, Osmanlı bürokrasi ağını gözler önüne sererken, devletin en küçük yönetim birimindeki bir meselenin bile kurumlar arası eşgüdümle nasıl takip edildiğini ve çözüme kavuşturulabildiğini de göstermektedir.

Belgelere konu olan tüm olumsuz girişimlerin kökeninde İslam'ın ilk dönemlerinden itibaren birbirinin devamı şeklinde yürütülen Batı kaynaklı sistemli faaliyetlerin olduğu gerçeğini bir kez daha hatırlamak gerekmektedir.

Zira XIX. ve XX. yüzyıl Batı kaynakları incelendiğinde birkaç istisna dışında çalışmalardaki ortak temanın İslam'ın Hz. Muhammed tarafindan üretildiği yönünde olduğunu söylenebilir. Batı düşüncesi, Kur'an’1 Hz. Muhammed'in bir ürünü olarak gördüğü için Kur'an'da Yahudilik ve Hıristiyanlık ile ilgili beyanlardan da bizzat Hz. Muhammed'i sorumlu tutmakta ve onun şahsiyetine yönelik hakaretlerin sebebi saymaktadır (Korkut, 2008: 30, 48). Bat1 düşünce tarihinde $\mathrm{Hz}$. Muhammed'in hayatı ile ilgili eserlerin birçok bakımdan önemli olduğu aşikârdır. Çünkü Batı'da İslam hakkındaki önyargılar, çoğunlukla Hz. Muhammed'in hayatı hakkındaki yanlış bilgilerden yola çıkılarak oluşmuştur. Eğer, Hz. Muhammed'in hayatı hakkında Batı toplumları sağlıklı bir bilgilenme imkânı bulup, bu konuda ortak bilince sahip olurlarsa, bu birçok bakımdan İslam hakkındaki bazı önyargıların da sona ermesini sağlayabilir (Korkut, 2008: 37).

Müslümanlar yaşanan tüm olumsuzluklardan ve ön yargılardan kurtularak kendi din ve peygamberi hakkındaki tüm doğru bilgileri özümsemek ve örnek yaşantılarıyla dünya kamuoyunda tahkire değil takdire layık olmalıdır. Bugün kısmen devam ettiği düşünülen bu tür girişimler konusunda İslam 
dünyasının çok dikkatli olması gerekmektedir. İçinde bulunduğumuz çağın iletişim olanakları göz önüne alındığında İslam dini ve Hz. Muhammed'e yönelik bu tür girişimlerin yayılma hızı oldukça endişe verici boyutlara ulaşabilir. Bu nedenledir ki, bu ve benzeri fazahat girişimlerine, hezeyanlara karş1 devletin ilgili kurumları tarafindan tüm kamusal iletişim ortamlarında, bilgi kaynaklarında titiz bir takibin yapılması büyük önem arz etmektedir. Burada önemle vurgulanması gereken bir diğer husus, devletin kurumları arasındaki yurt içi ve yurt dışı haberleşme ve eşgüdüm kabiliyetidir. Zira İslam dini ve Türk milletine yönelik tahfif ve tahkir edici girişimler yalnızca ülkemizi değil tüm Türk-İslam coğrafyasına yönelik bir hadsizliktir. Geçmişte olduğu gibi bugün de millî̀ ve manevî değerlerimizin İslamî ve tarihî hakikatlere uygun biçimde gelecek nesillere aktarılması için caydırıcı ve önleyici tedbirlerimizi sürekli gözden geçirmek, güncellemek durumunda kalabiliriz. Bu tedbirlerin yanı sıra bu tür girişimlerin etki ve nüfuzunu kırmanın en güvenilir yollarından biri, toplumun her kesimine İslam Dini ve âlemlere rahmet olarak gönderilen Hz. Muhammed ile ilgili doğru ve tam bilgilerin öğretilerek özellikle gençlerimiz ve çocuklarımızın zihninde ortak ve sarsılmaz bir manevî bilincin inşa edilmesidir.

\section{Teşekkür}

Desteklerinden dolayı Ayaz Doğu Rukancı ve İrfan Akça'ya teşekkür ederiz. 


\section{KAYNAKLAR}

Akpınar, Mahmut (2015). "Osmanlı Hariciyesi'nde Yaklaşık Kırk Y11: Mahmud Esad Paşa (1837-1895)”, FSM İlmî Araştırmalar Dergisi (5, Bahar): ss. 29-51.

Aydın, M. Akîf (2020). Osmanlı Hukuku: Devlet-i Aliyye’nin Temeli, İstanbul: İSAM.

Bosworth, C. E (1970). "A Dramatisation of the Prophet Mohammed's Life: Henri de Bornier's "Mahomet”, Numen 17 (2, August): 105-117.

Devellioğlu, Ferit (1962). Osmanlıca-Türkçe Ansiklopedik Lügat: Eski ve Yani Harflerle, İstanbul: Doğuş Matbaası.

Görgün, Hilal (2005). "Muhammed”, TDV İslam Ansiklopedisi c.30 içinde (ss. 476-478), İstanbul: TDV.

Kallek, Cengiz (1992). "Henri de Bornier (1825-1901)”, TDV İslam Ansiklopedisi c. 6 içinde (ss. 292-293), İstanbul: TDV.

Kalın, İbrahim (2019). İslam ve Batı, İstanbul: İSAM Yayınları.

Karlığa, Bekir (2004). İslam Düşüncesinin Batı Düs̆üncesine Etkileri, İstanbul: Litera Yayıncilik.

Korkut, Şenol (2008). "Batı Düşüncesinde İslam ve Hz. Muhammed (s.a.s.) İmaj1: Genel Bir Okuma”, Marmara Üniversitesi İlabiyat Fakültesi Dergisi 34 (2008/1), ss. 5-54.

Köroğlu, Mehmet (2015). "İslam Hukukunda Ölüm Cezasını Gerektiren Suçlar”, Atatürk Üniversitesi İlahiyat Fakültesi Dergisi (43), ss. 214-238.

Kütükoğlu, Mübahat (2018). Osmanl Belgelerinin Dili (Diplomatik), 4. Bask1. Ankara: Türk Tarih Kurumu.

Özarslan, Selim (2007). "Hz. Peygamber'e Yönelik Saygısızlıklar, Kelam Araștırmaları 5 (2), ss. 63-84.

Polat, Nazım H. (2000). "İctihad”, TDV İslam Ansiklopedisi c. 21 içinde (ss. 446-448), İstanbul: TDV.

Redhouse, James William (1856). Redhouse's Turkish Dictionary: In Two Parts: English and Turkish and Turkish and English, London: Wyman and Sons.

Şemseddin Sâmî (2001). Kâmûs-ı Türkî, İstanbul: Çağrı Yayınları. 
Şirin, İbrahim (2011). "Gazete, Kitap, Tiyatro Karşısında İmajını Korumaya Çalışan Sultan ve Maiyeti: Sultan II. Abdülhamid ve Ahmed Mermi”, Cyprus International University Folklor / Edebiyat Dergisi 17 (66): ss. 39-55.

Yıldız, Hasan Basri (2018). “Hz. Peygamber'e Hakaretin Cezası”, Usûl İslam Araștırmaları (30, 2018): ss. 133-160.

\section{Belgeler}

BCA 51.0.0.0.0.5.43

BOA DH. MKT. 1388-32

BOA DH. MKT. 1911-87

BOA DH. MTV. 21-31

BOA İ. DUİT. 17-99

BOA İ. MVL. 233-8185

BOA MF. MKT. 26-65

BOA MF. MKT. 155-67

BOA MF. MKT. 251-13

BOA Y. A. HUS. 237-16

BOA Y. A. HUS. 284-74

BOA Y. A. HUS. 286-1

BOA Y. PRK. ASK. 161-19

BOA Y. PRK. DH. 8-79

BOA Y. PRK. EŞA. 12-28

BOA Y. PRK. EŞA. 28-12

BOA Y. PRK. HR. 18-23

BOA Y. PRK. MŞ. 6-52

BOA Y. PRK. ŞH. 5-81

BOA Y. PRK. ZB. 12-6

BOA Y. PRK. ZB. 13-4 


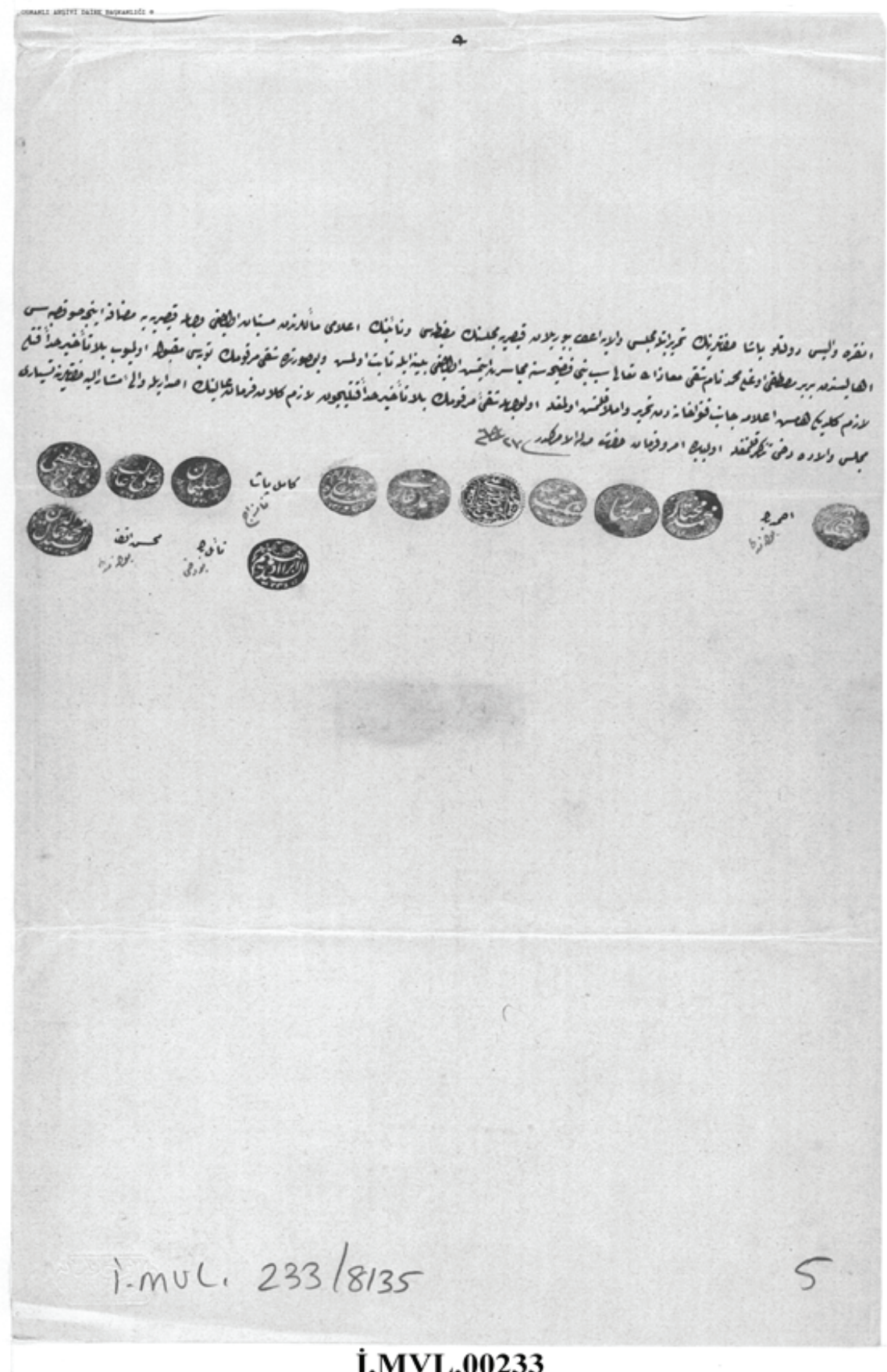

\section{I.MVL.00233}

\section{Belge 1}




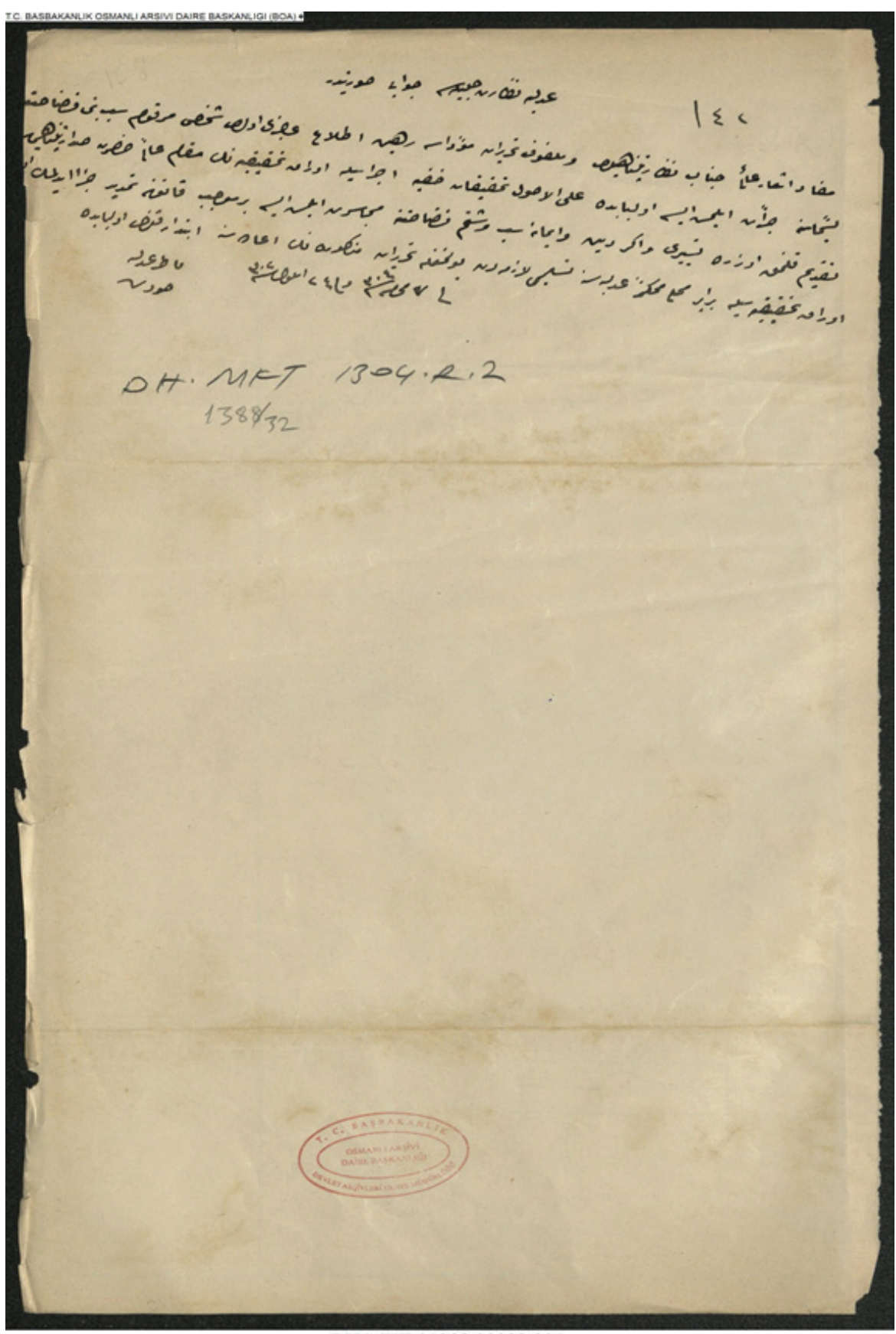

DH.MKT.01388.00032.001

\section{Belge-2}




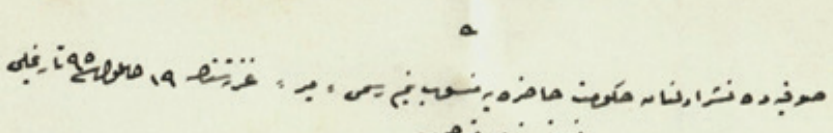

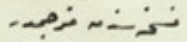

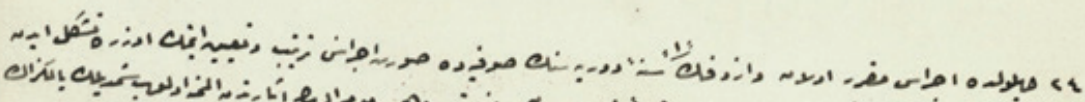

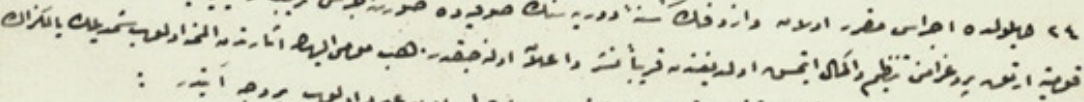

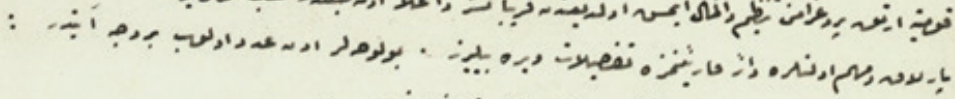

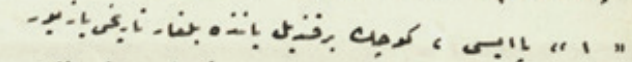

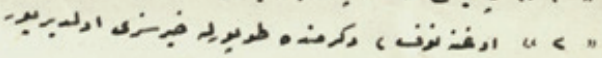

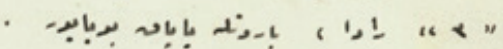

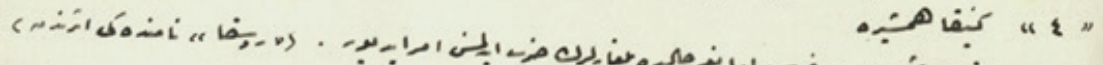

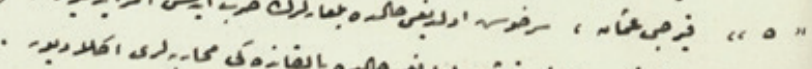

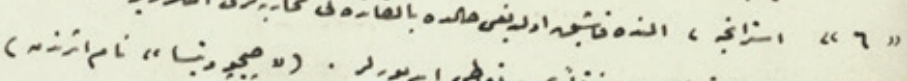

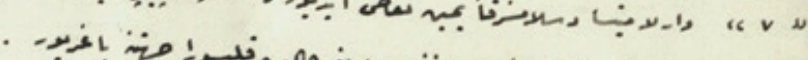

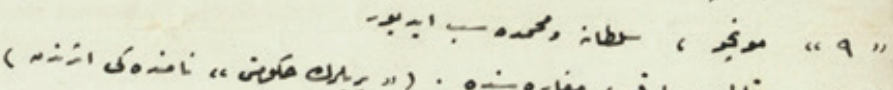

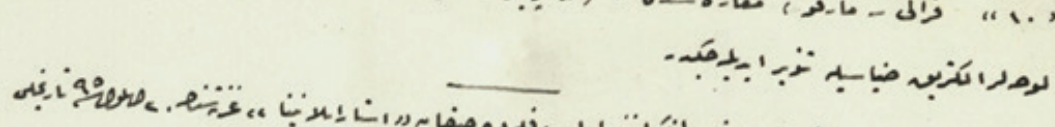

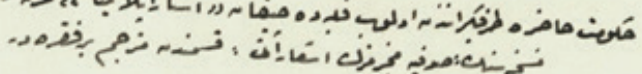

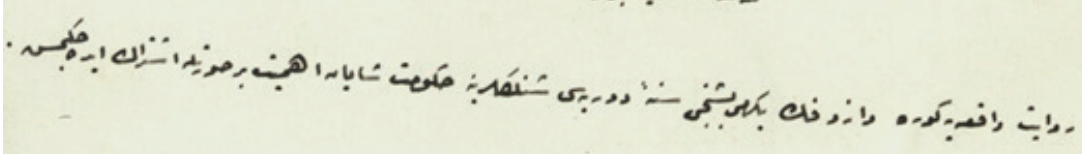

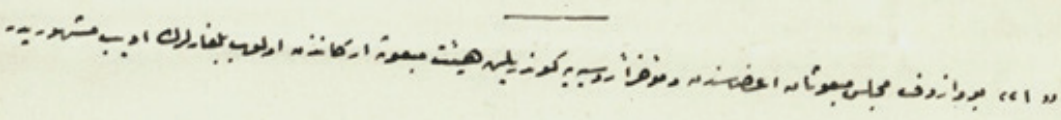

\section{Belge-3}




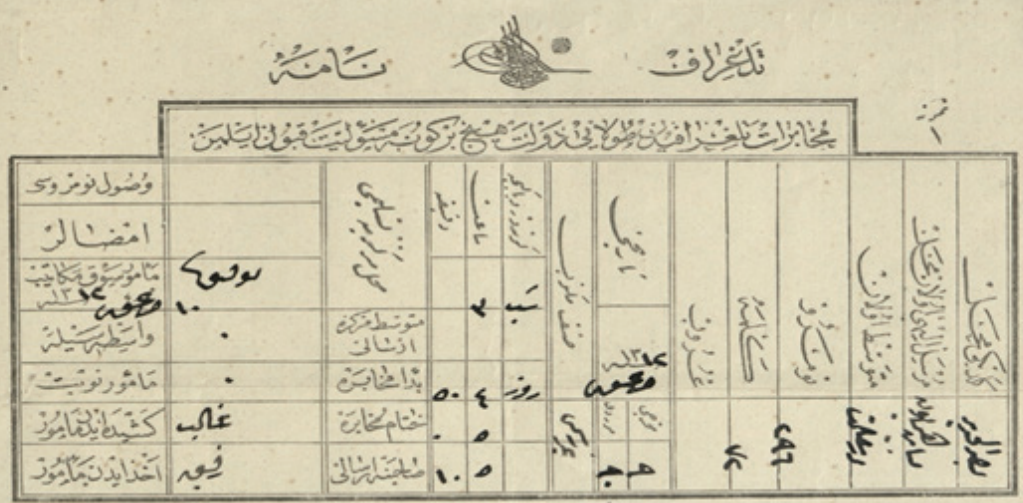

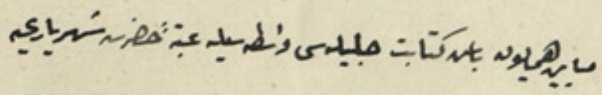

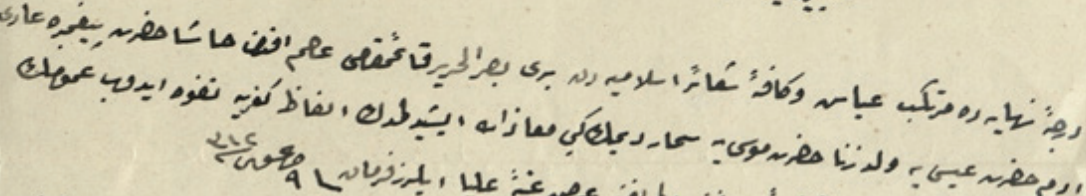

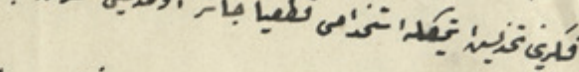

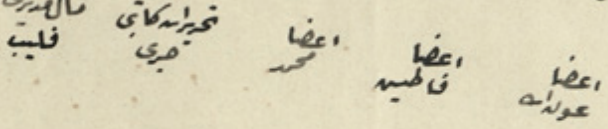

Y.PRK, ms $6 / 52$

Y.PRK.MŞ.00006.00052.001

\section{Belge-4}




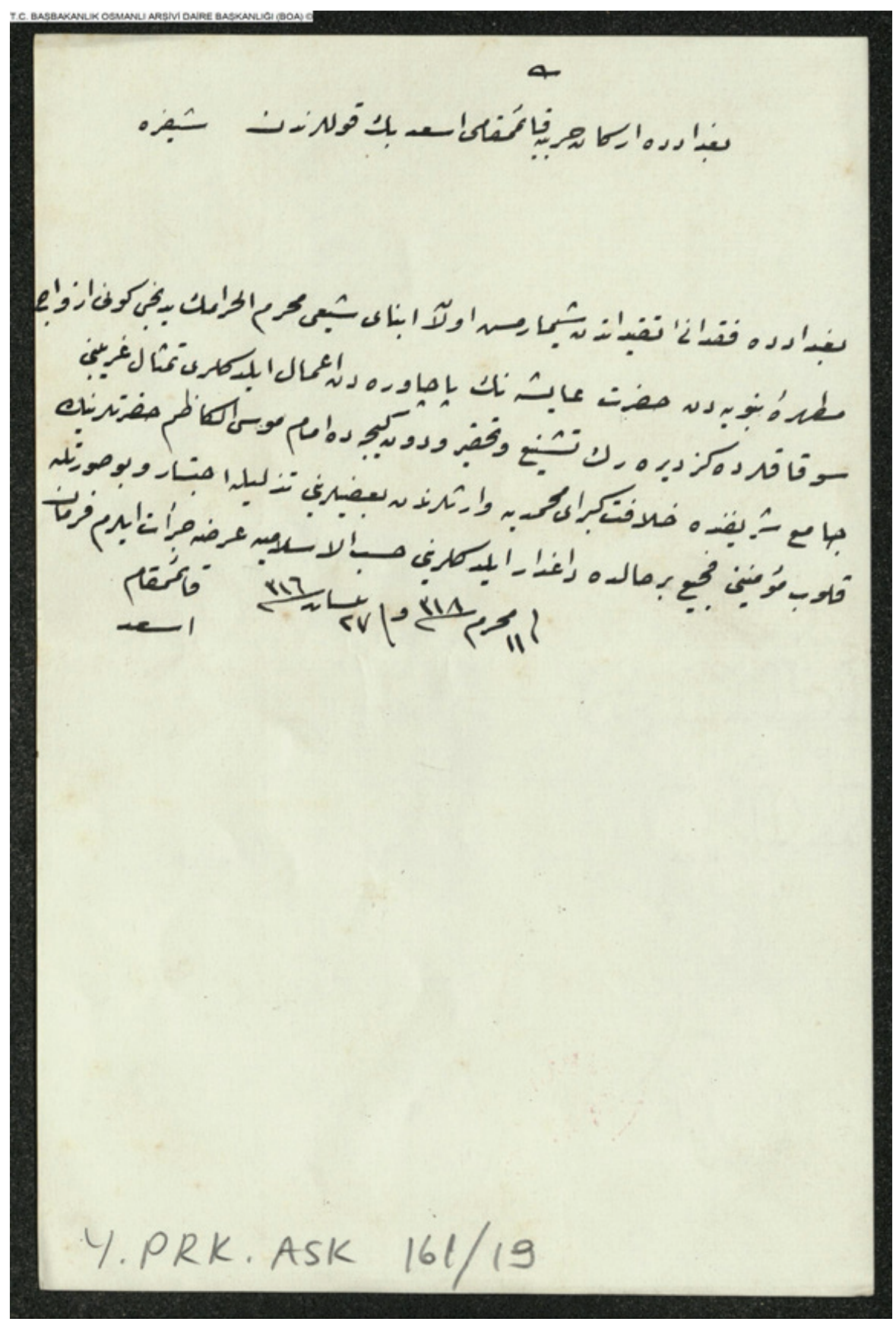

Y.PRK.ASK.00161.00019.001

Belge-5 

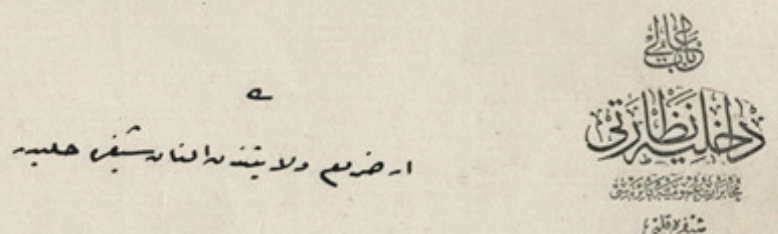

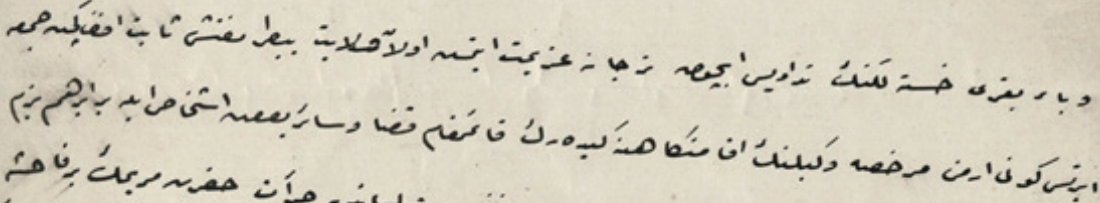

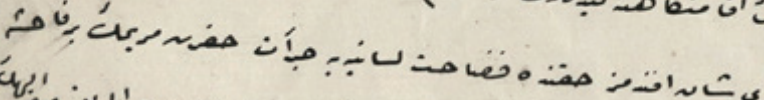

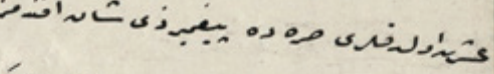

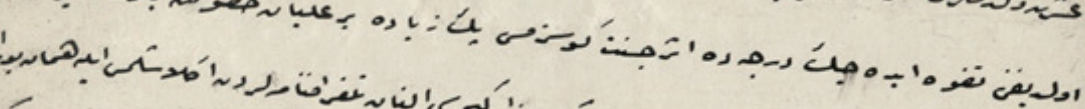

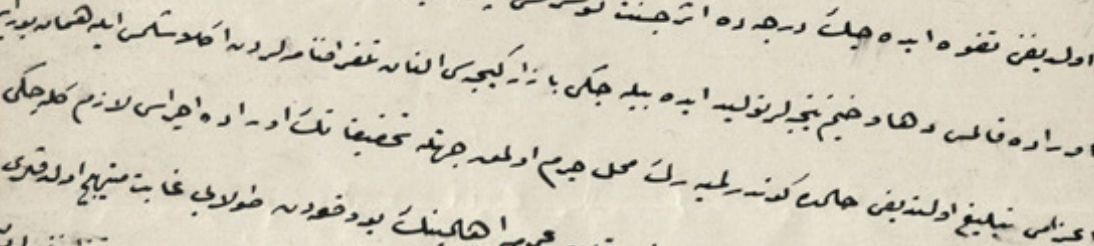

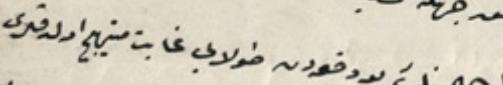

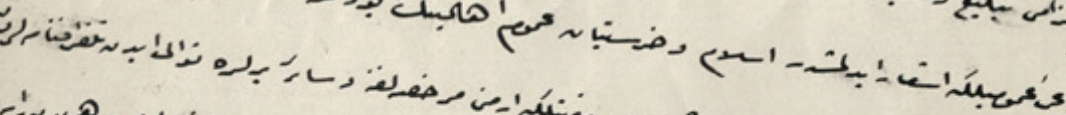

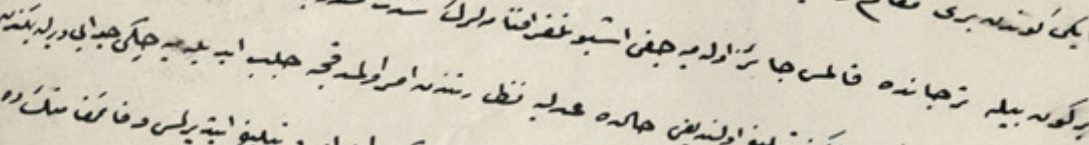

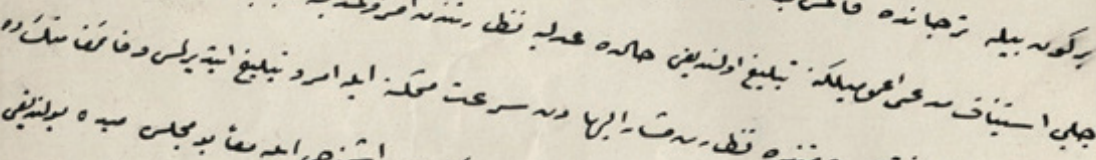

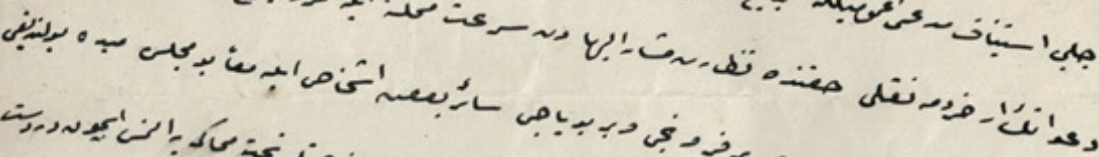

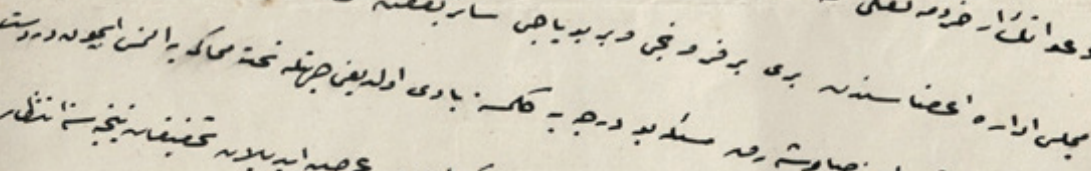

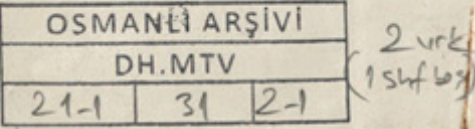

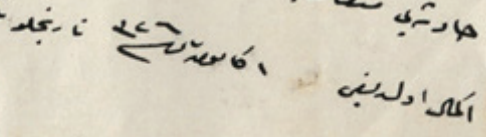

DH.MTV.00021.1.00031.002

\section{Belge-6}




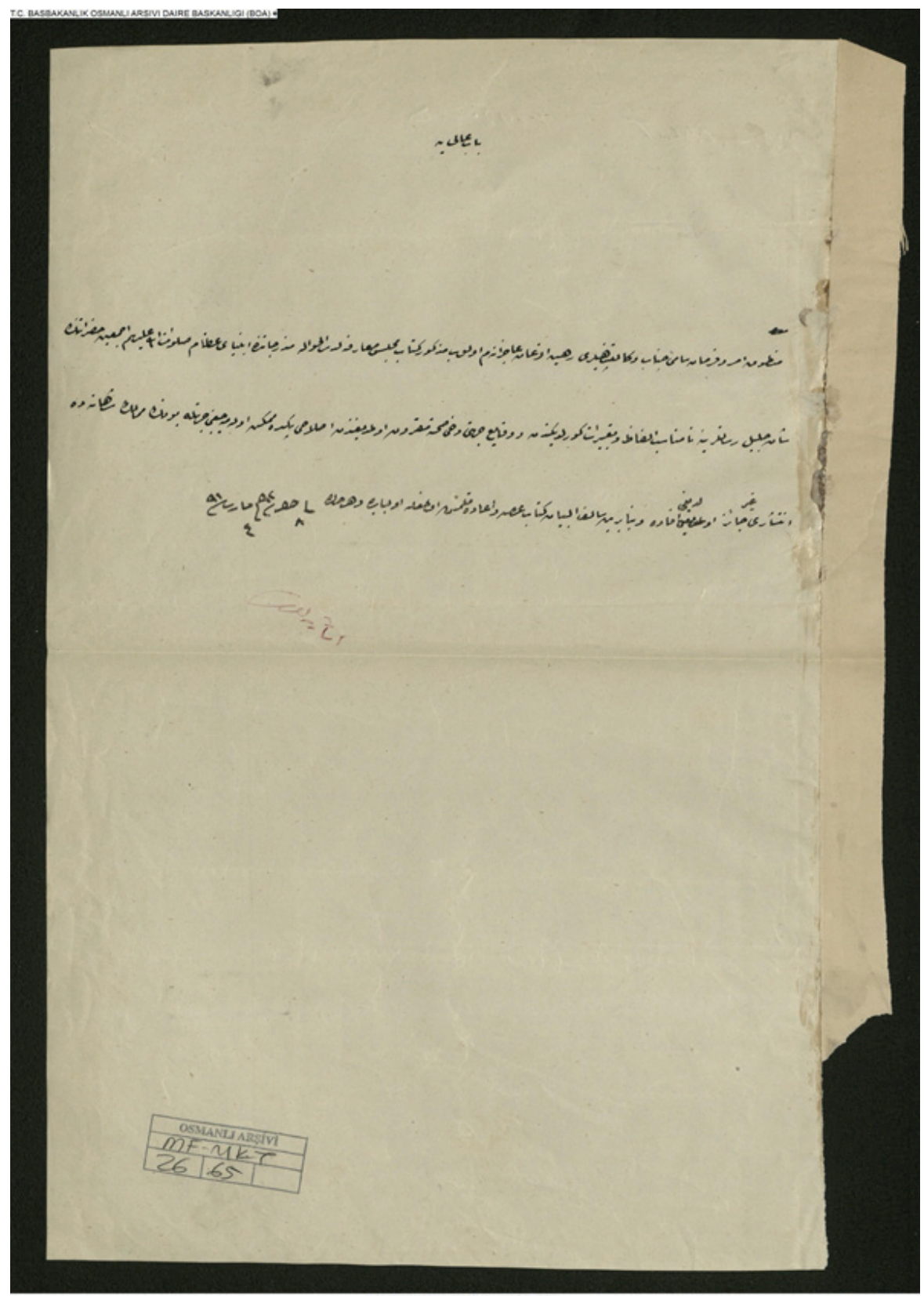

MF.MKT,00026.00065,001

\section{Belge-7}




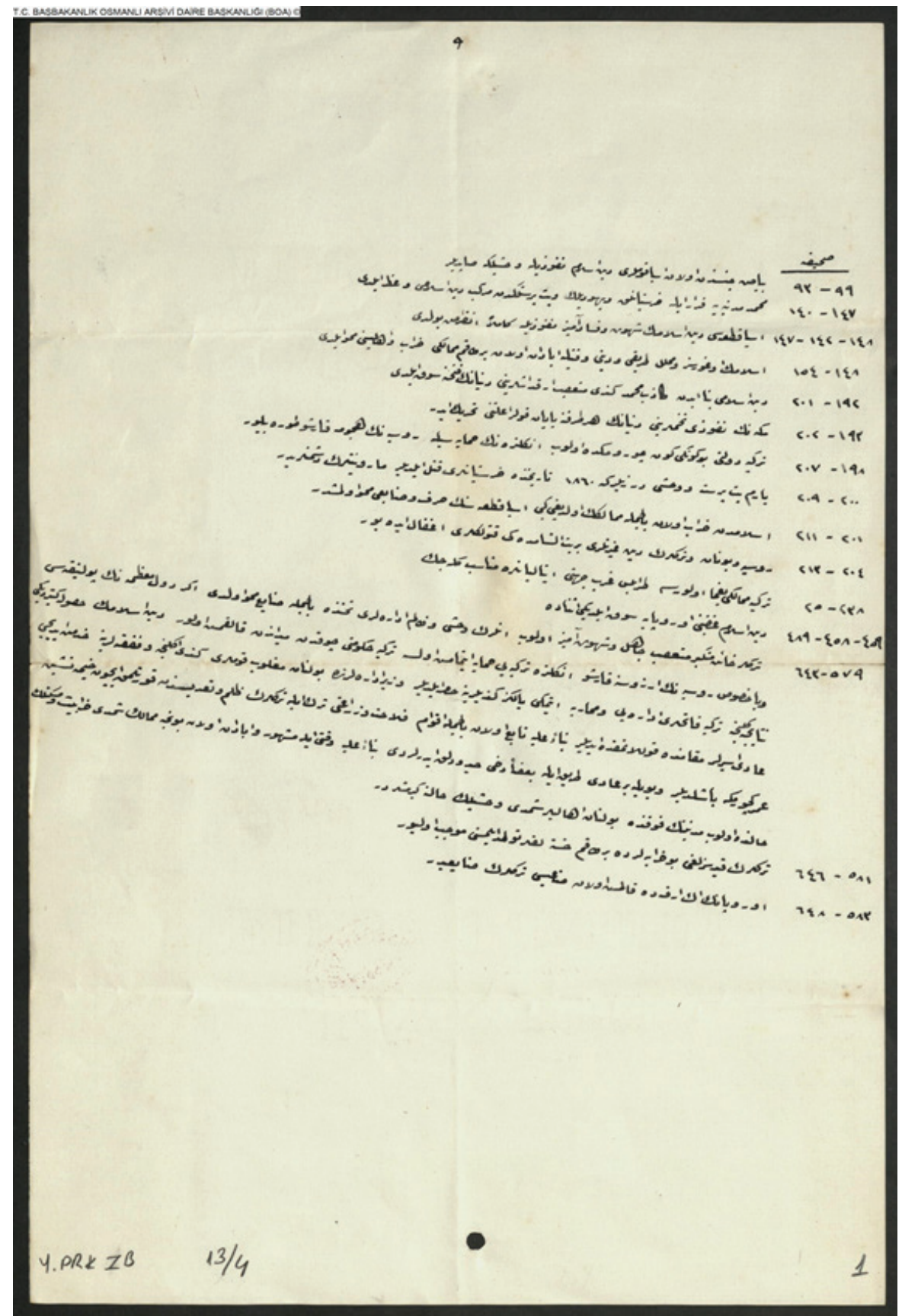

Y.PRK.ZB.00013.00004.001

Belge-8/1 


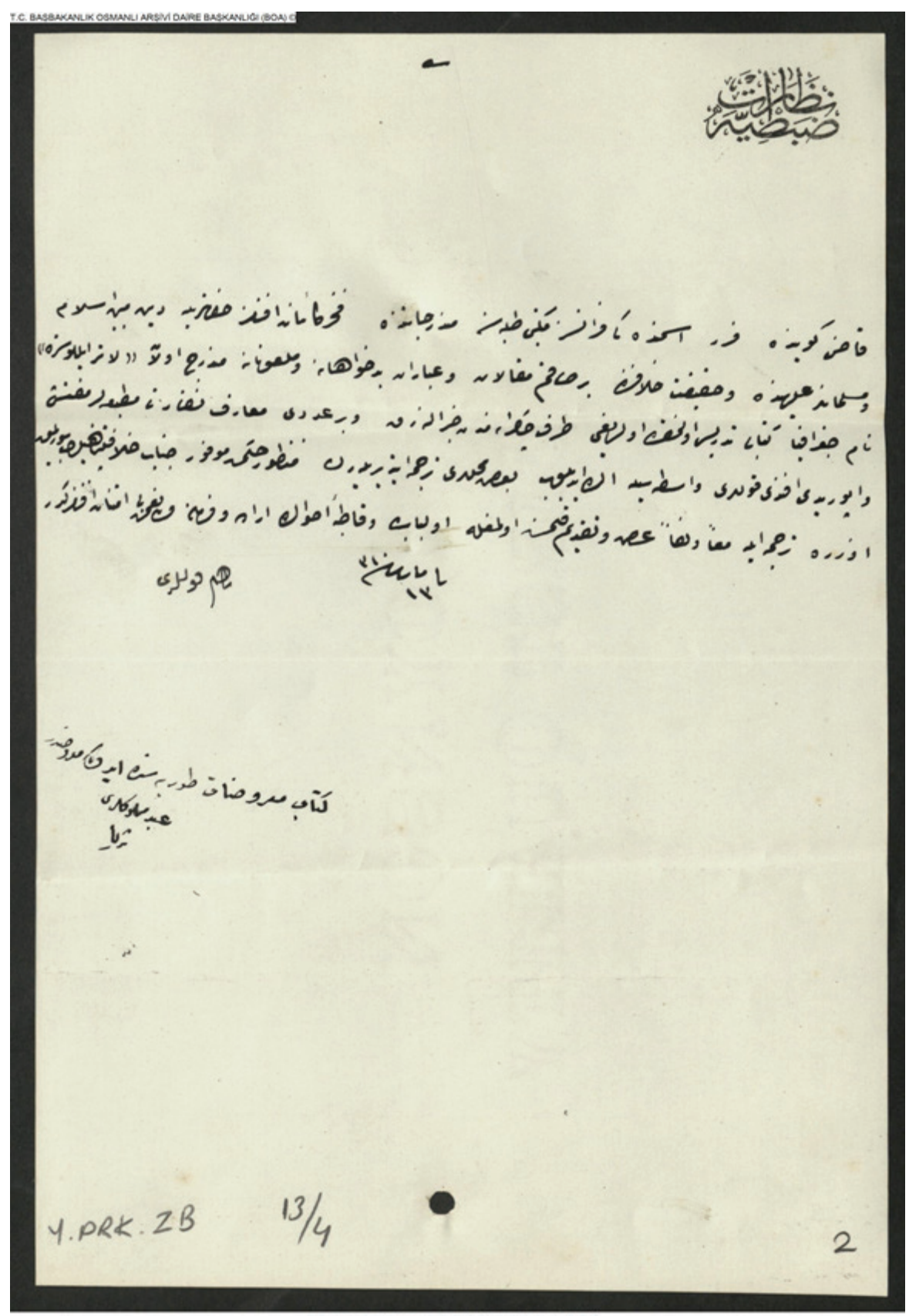

Belge-8/2 


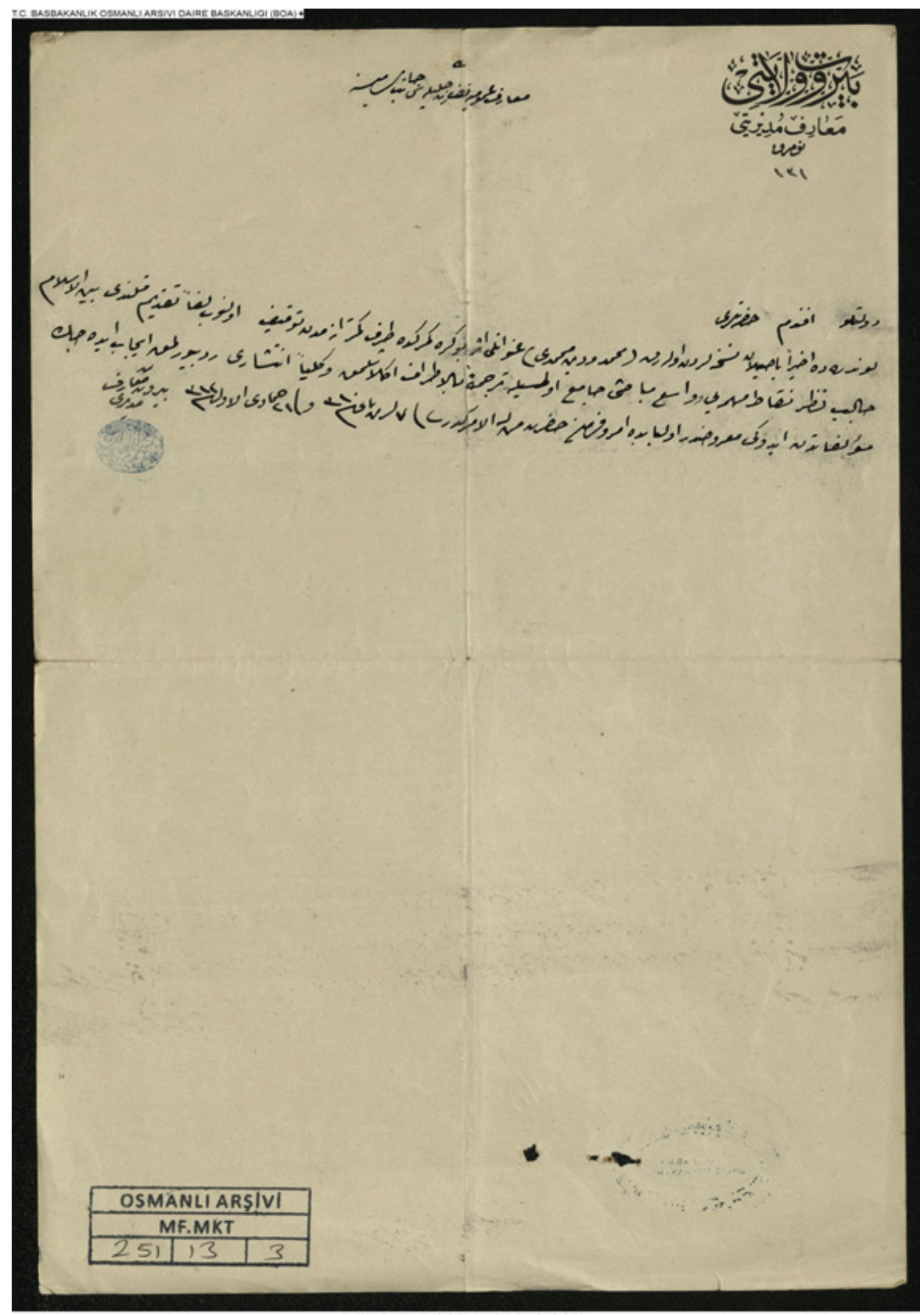

MF.MKT.00251.00013.003

\section{Belge-9/1}




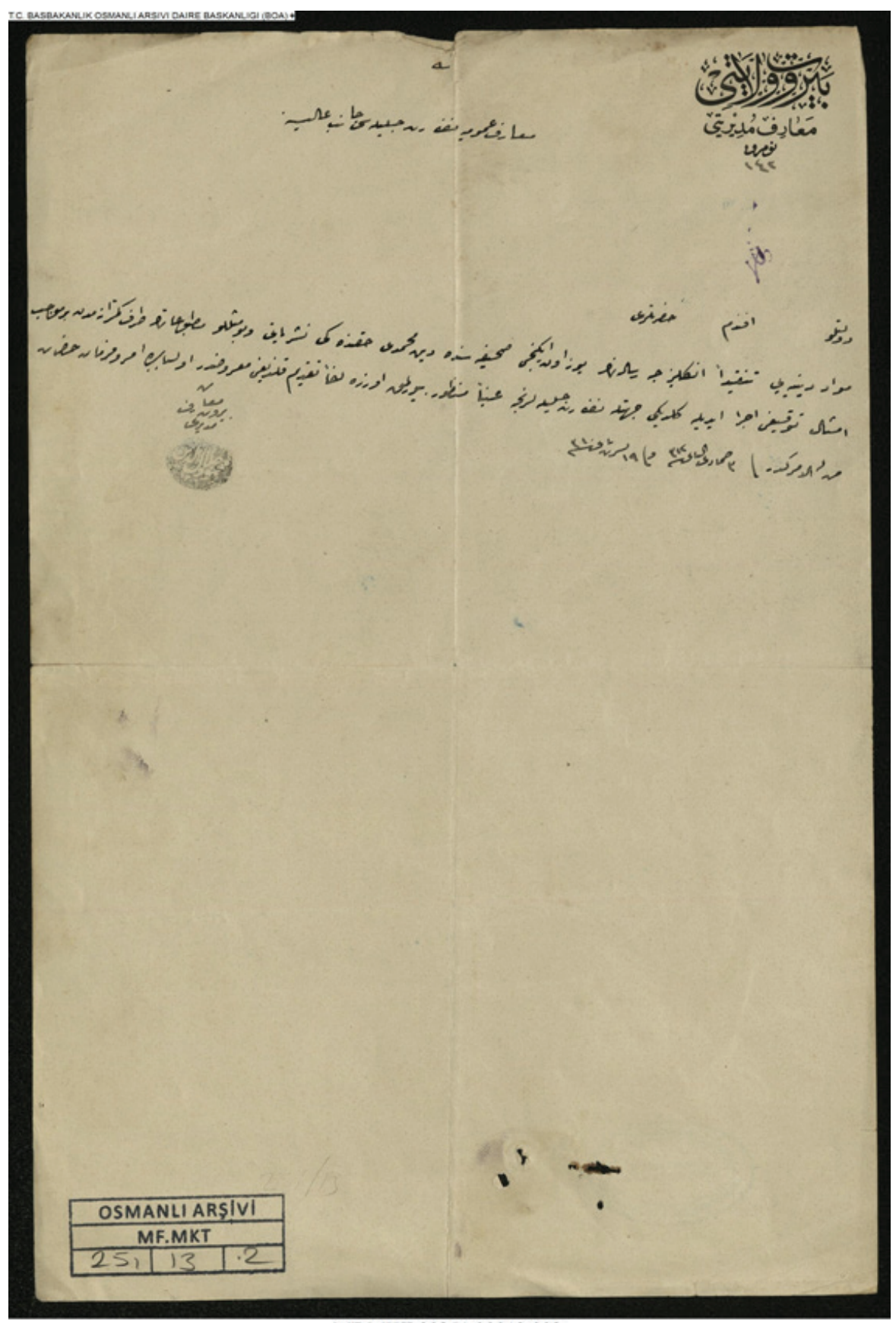

MF,MKT.00251.00013.002

\section{Belge-9/2}




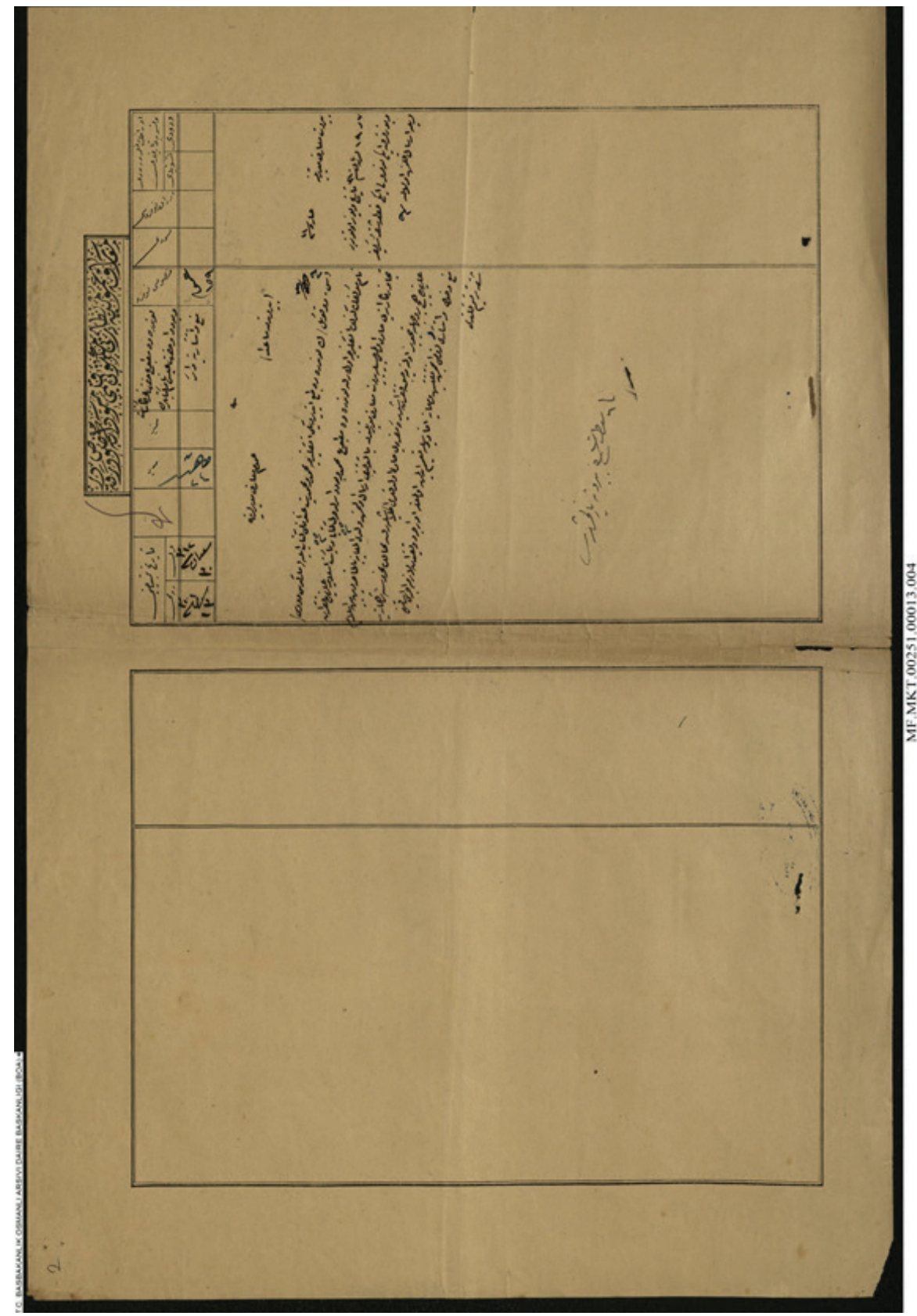

Belge-9/3 


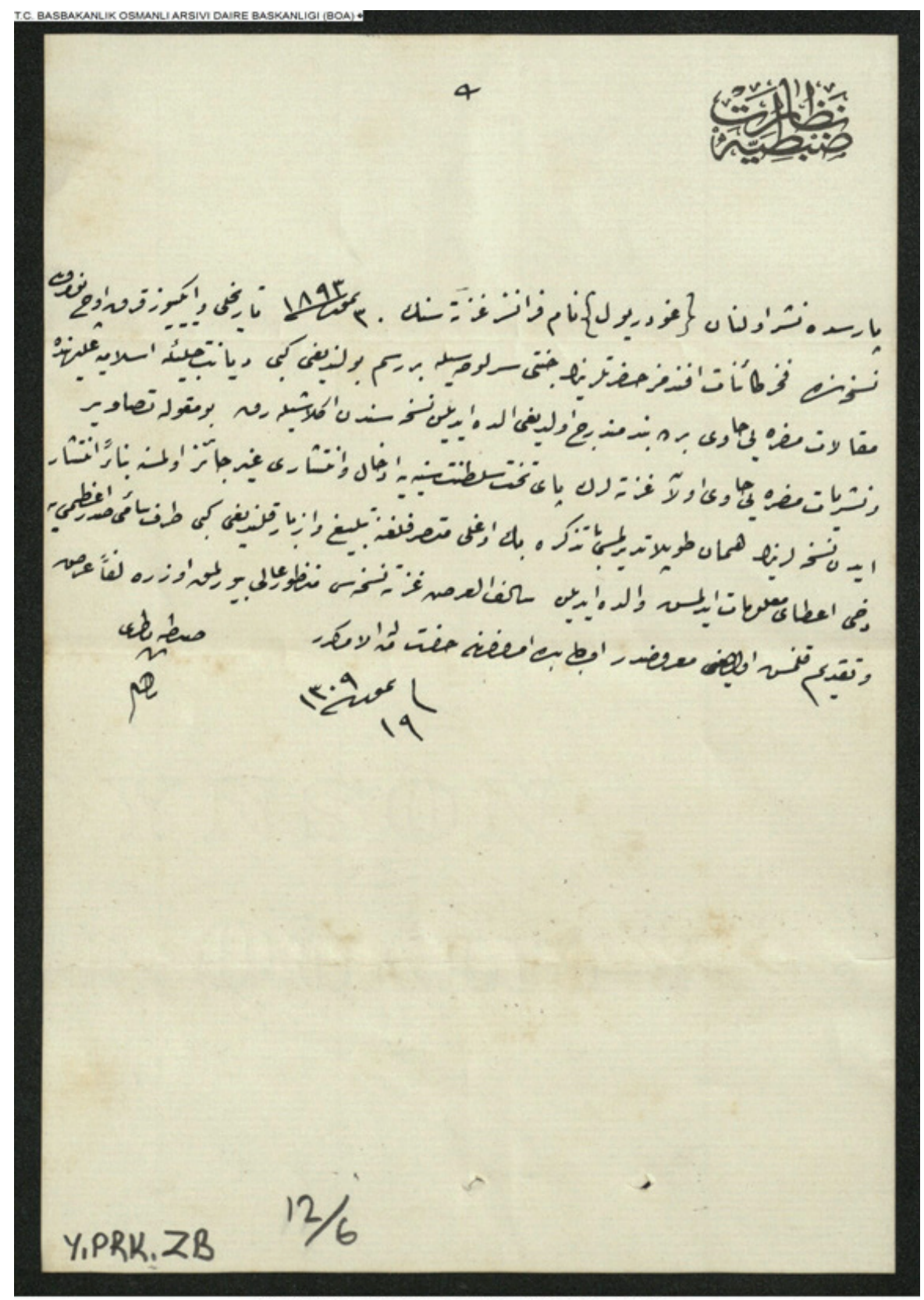

Y.PRK.ZB.00012.00006.001

Belge-10 


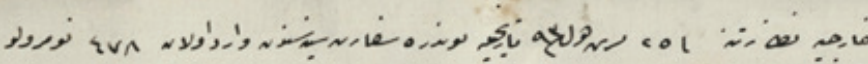

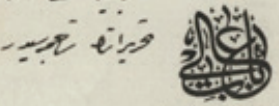

r

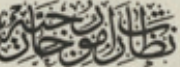

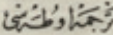

ver

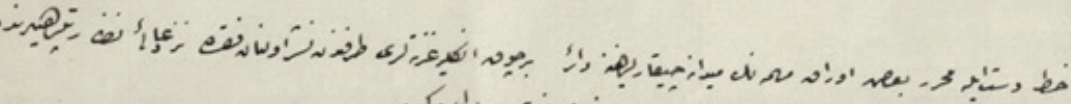

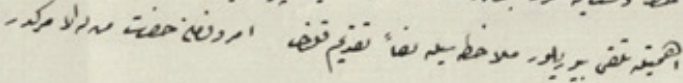

$$
=2 \text { e }
$$

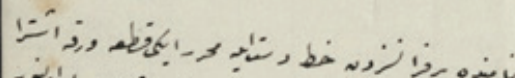

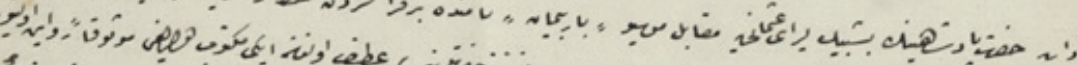

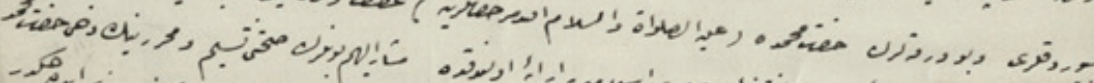

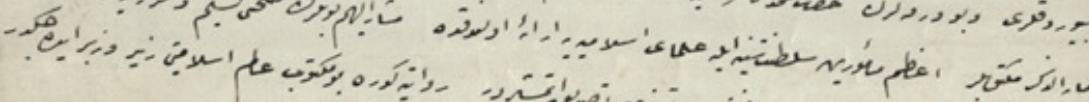

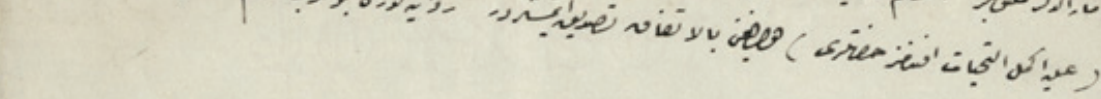




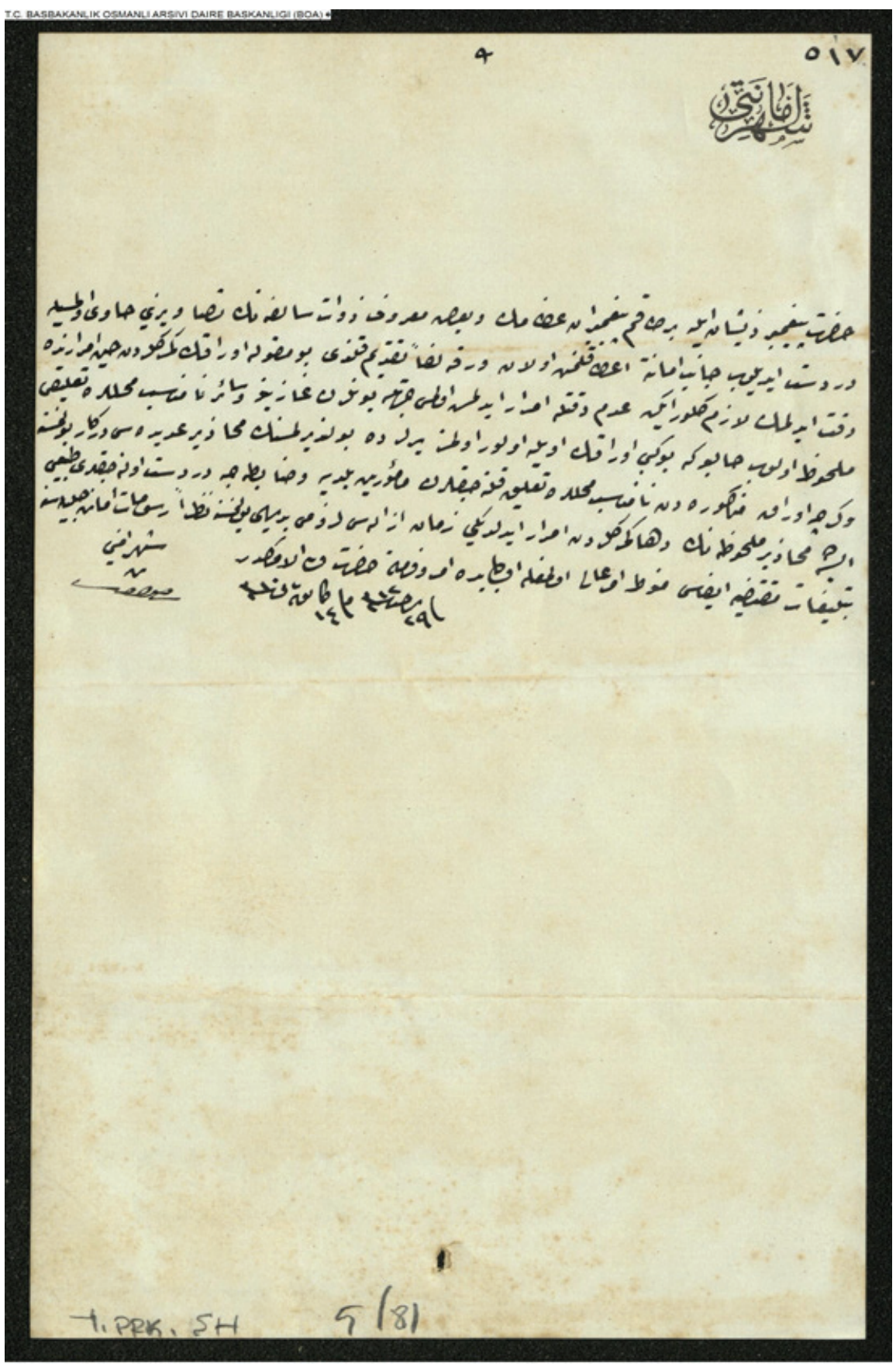

Y.PRK.ŞH.00005.00081.001

Belge-12 
4
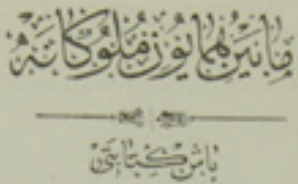

\a

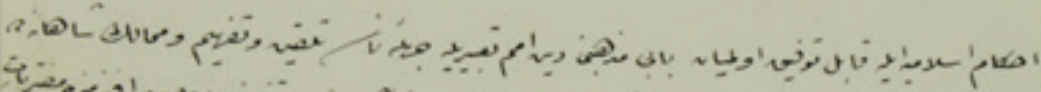

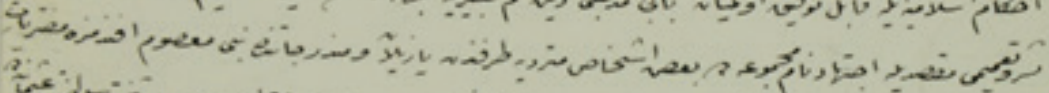

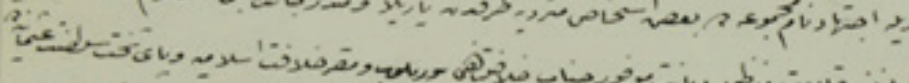

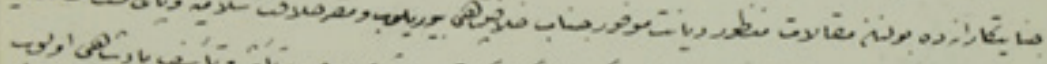

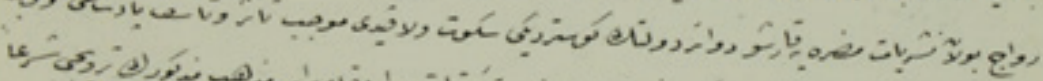
家 a

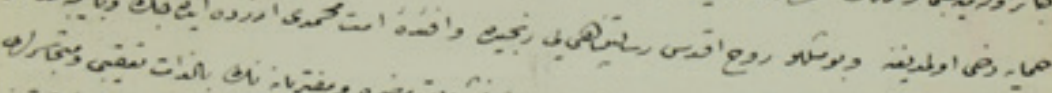
Fiv

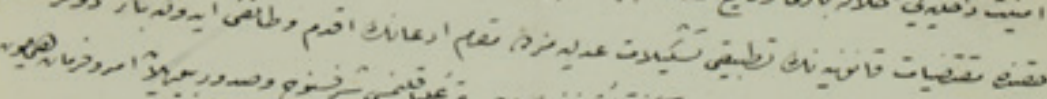

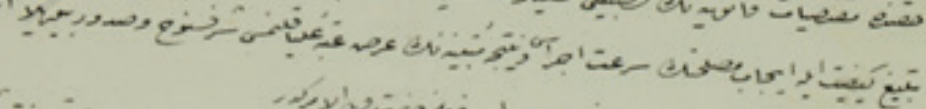
triab 2.

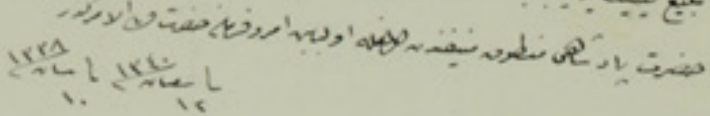

Duit $17 / 99$

Belge-13 


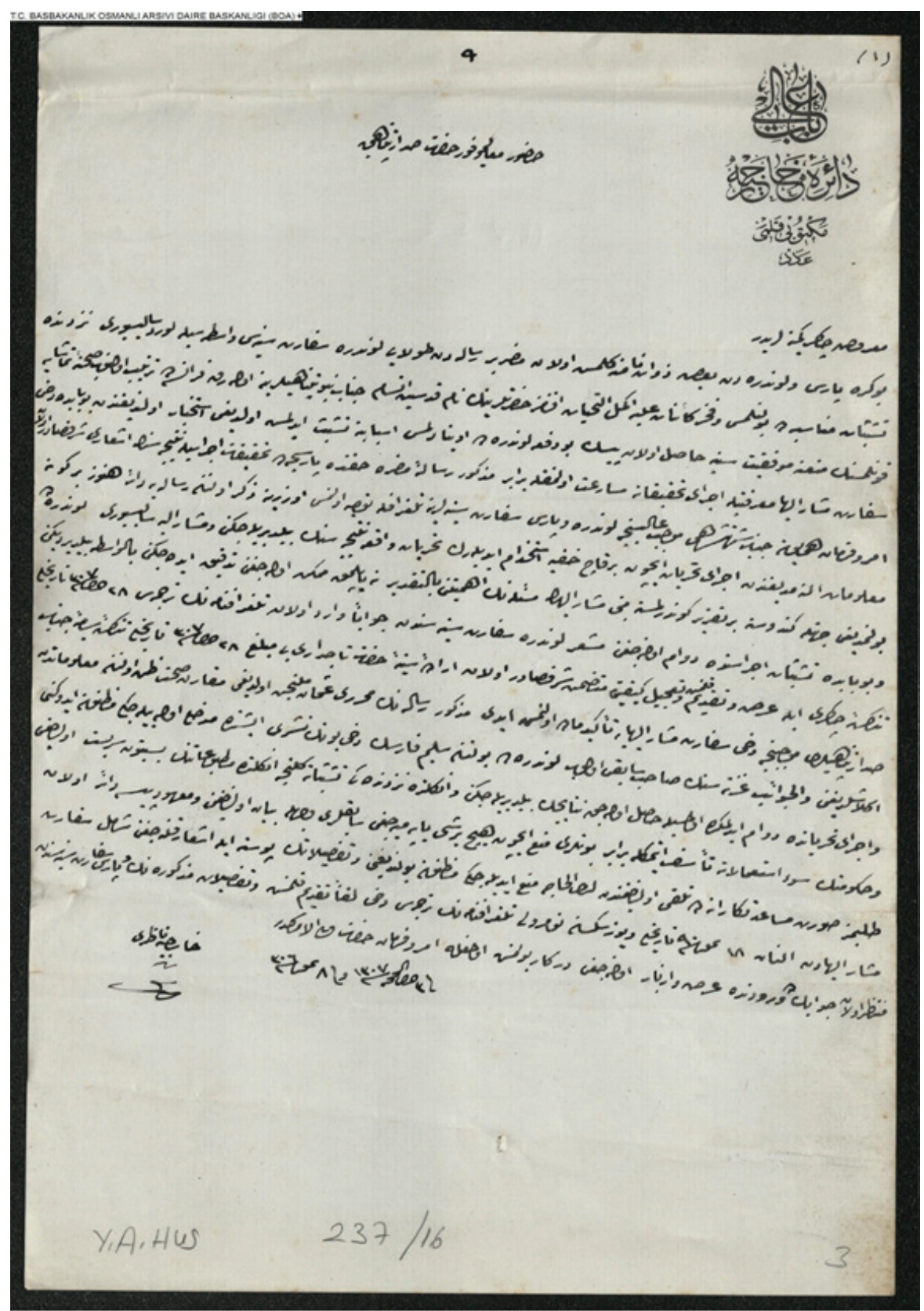

Y.A.HUS.00237.00016.003

\section{Belge-14}




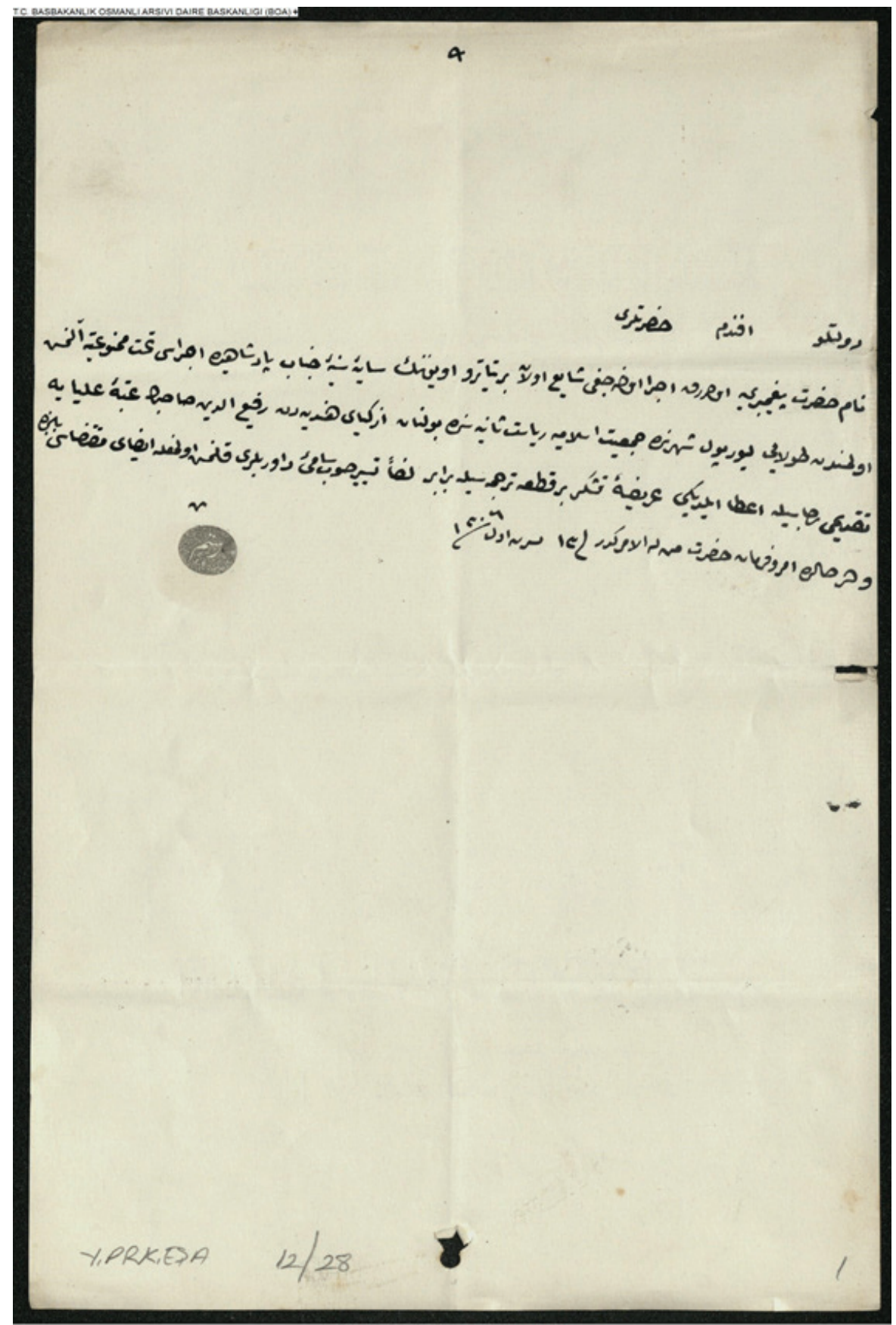

Y.PRK.ESA.00012.00028.001

Belge-15 


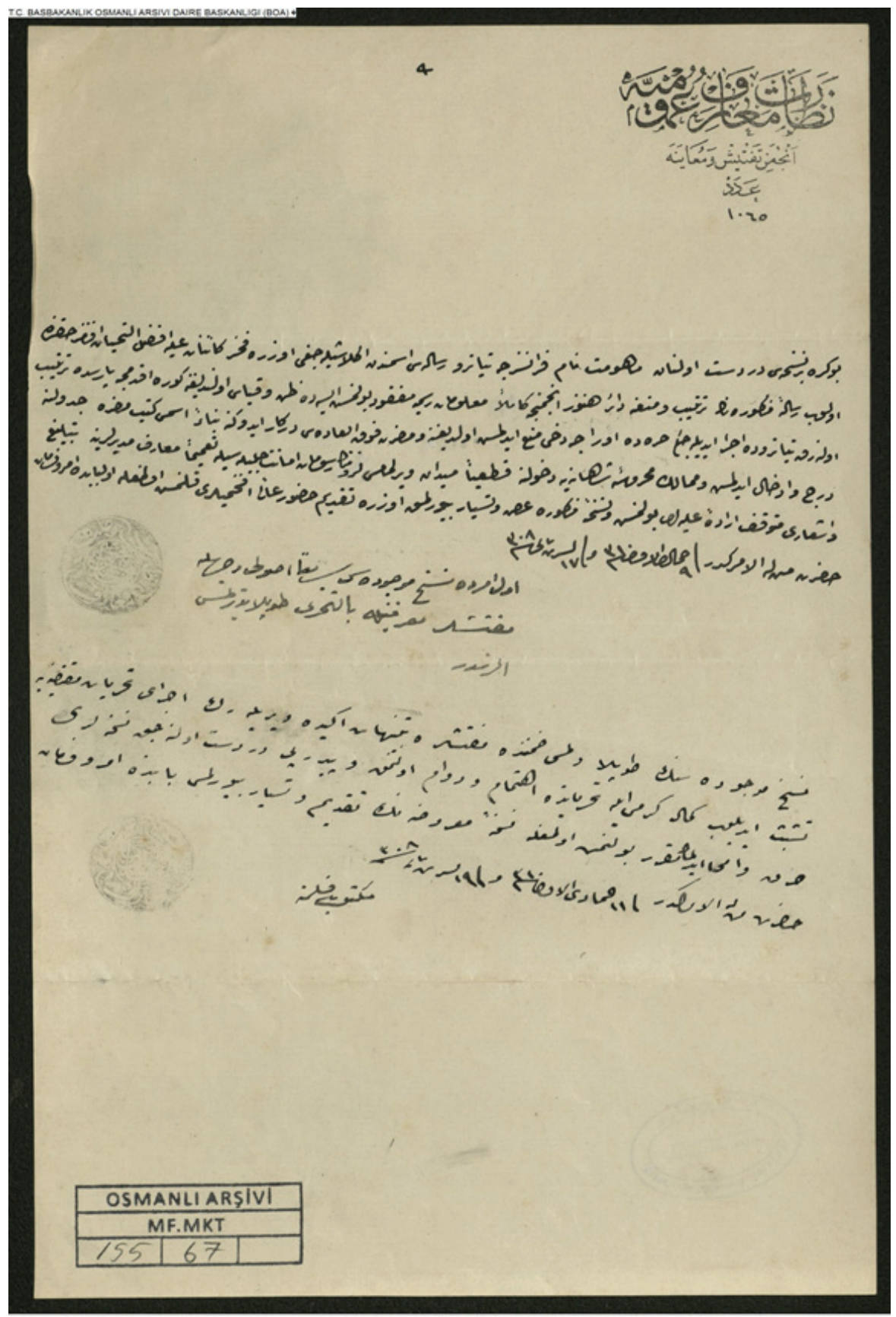

MF.MKT.00155.00067.001

Belge-16 


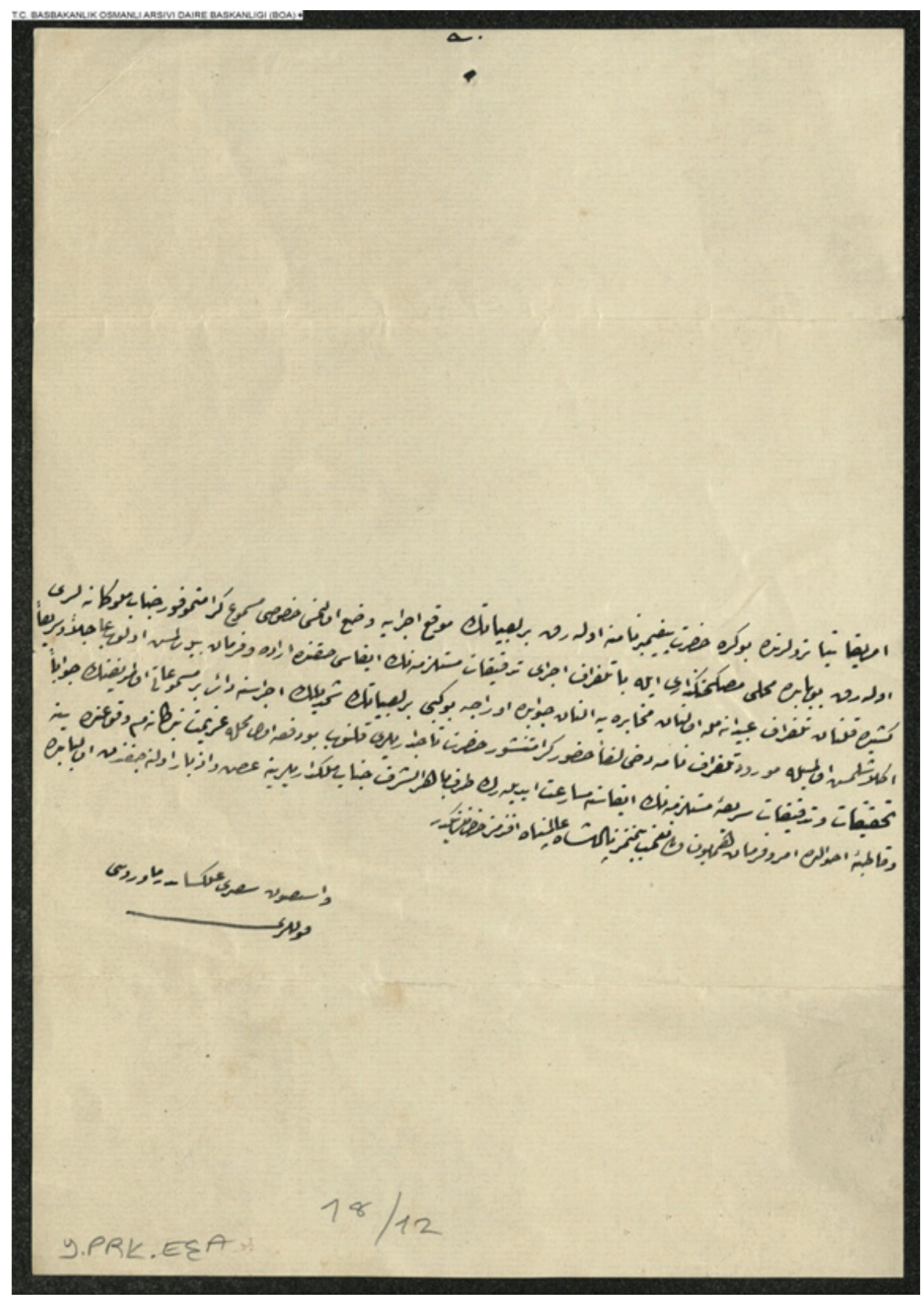

Y.PRK.EŞA.00018.00012.001

Belge-17 


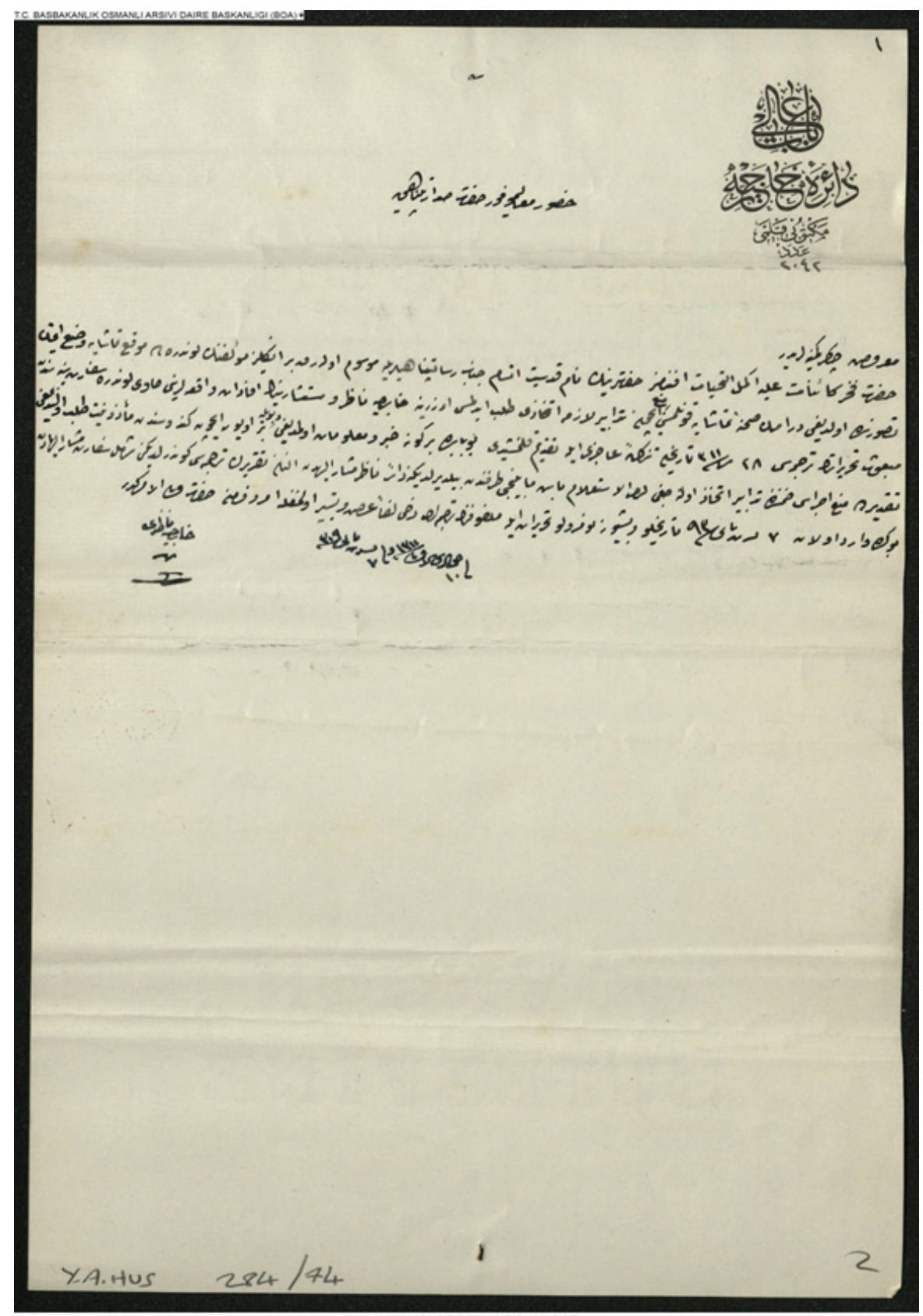




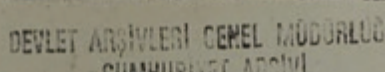
SUMHURIER ATaly!

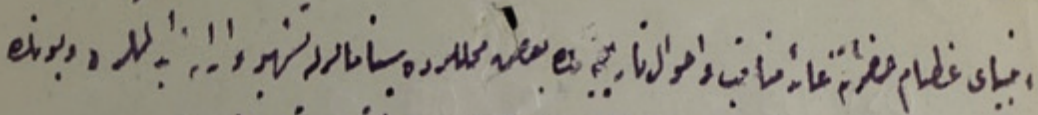

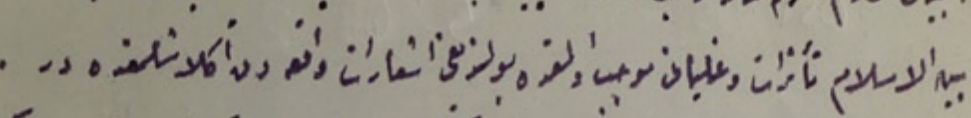
حسأ

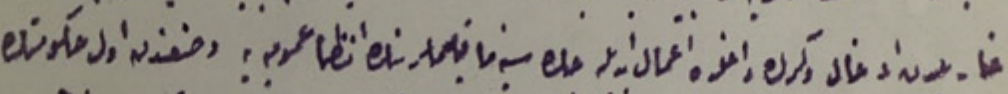

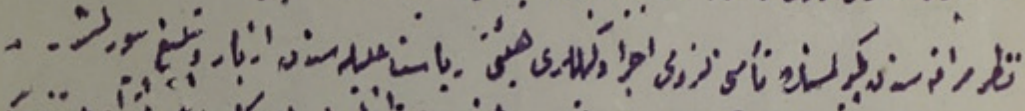
cow

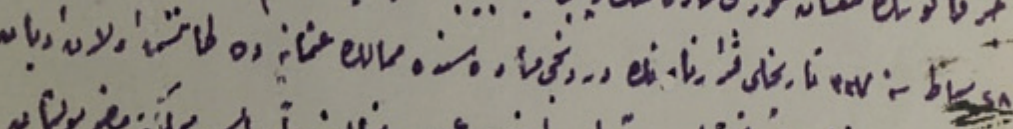

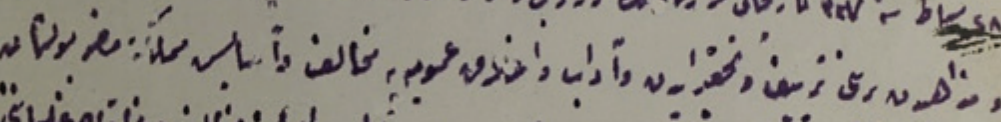

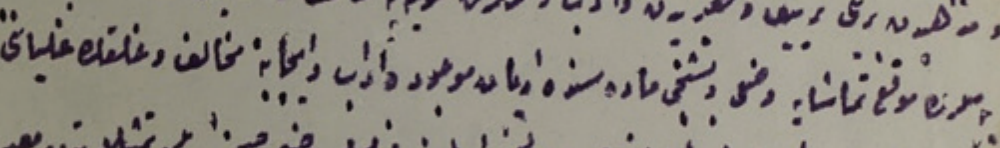
كره

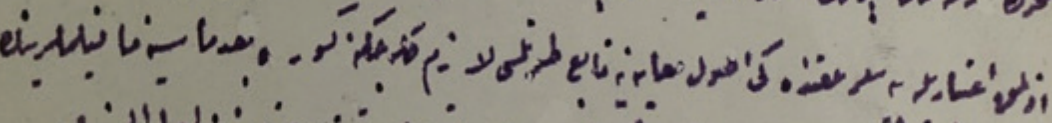

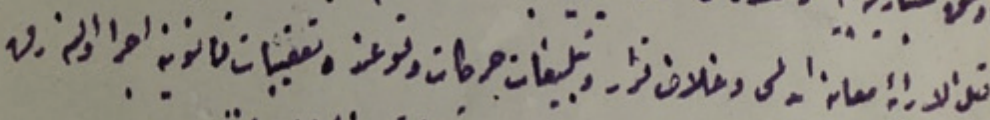

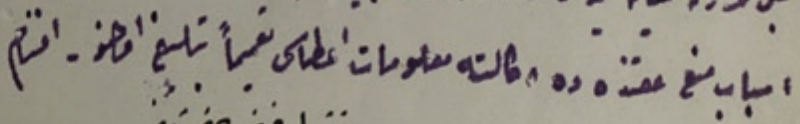

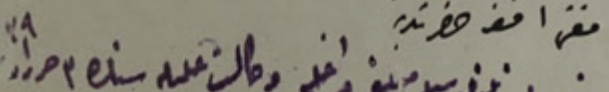

$$
\text { Ub, }
$$

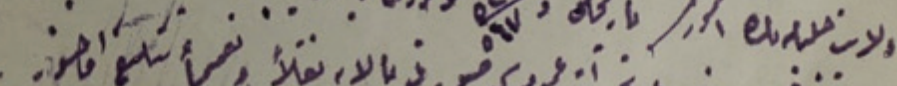$$
\text { , *. }
$$

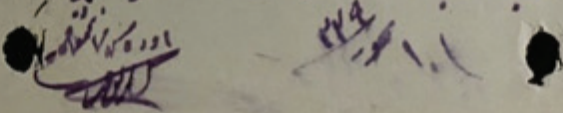

Belge-19 


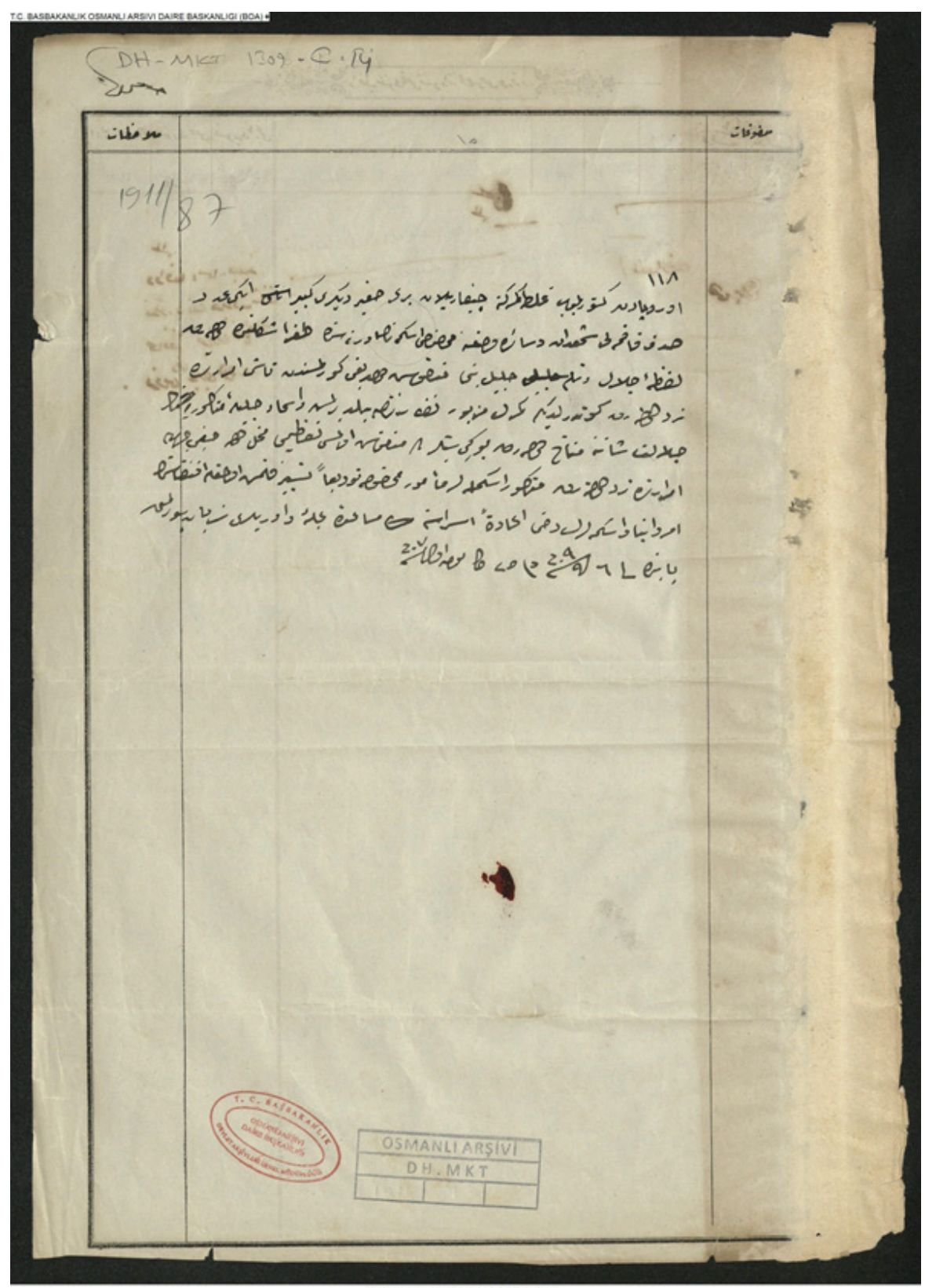

DH.MKT.01911.00087.001

Belge-20 


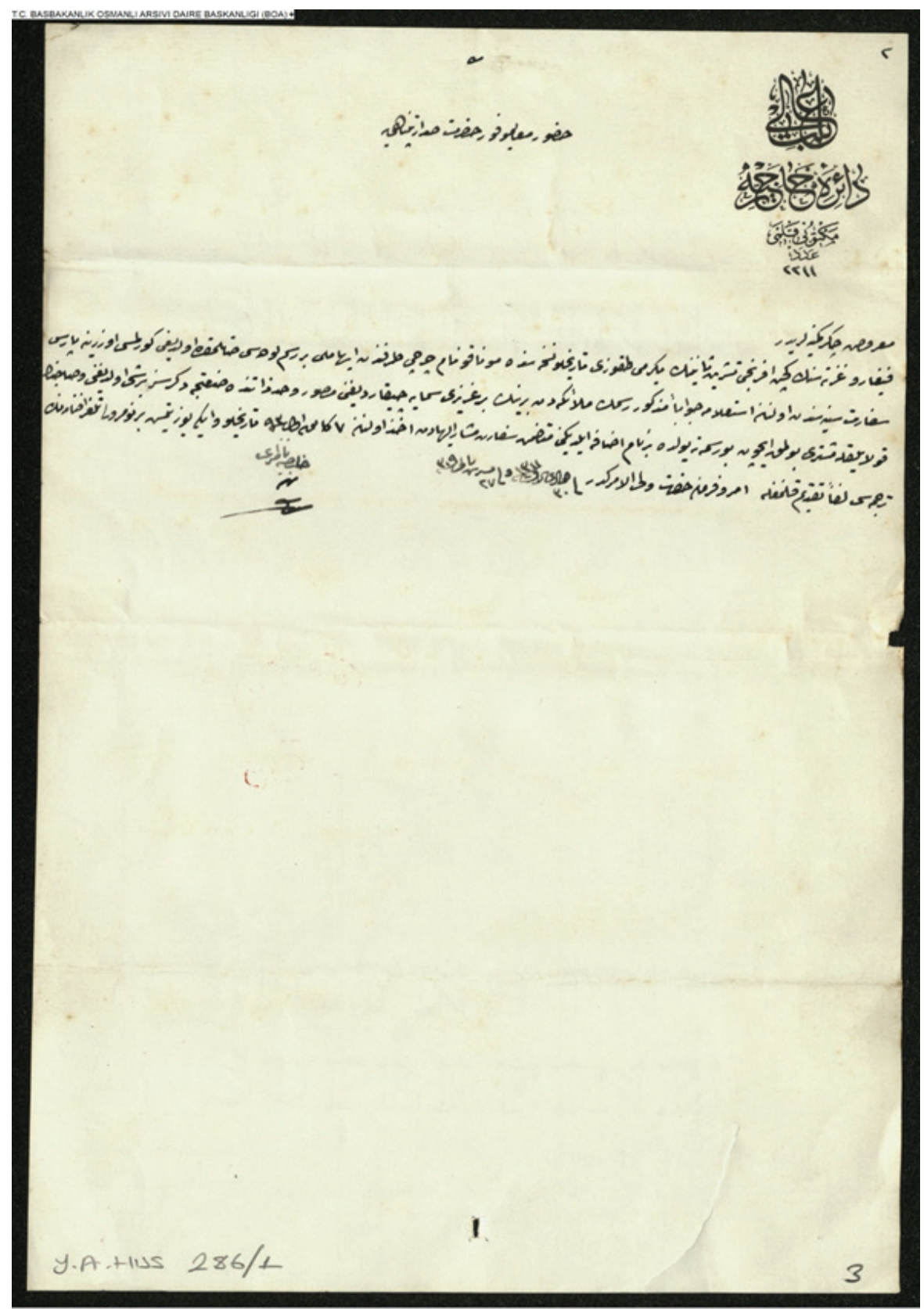

Y.A.HUS.00286.00001.003

Belge-21/1 


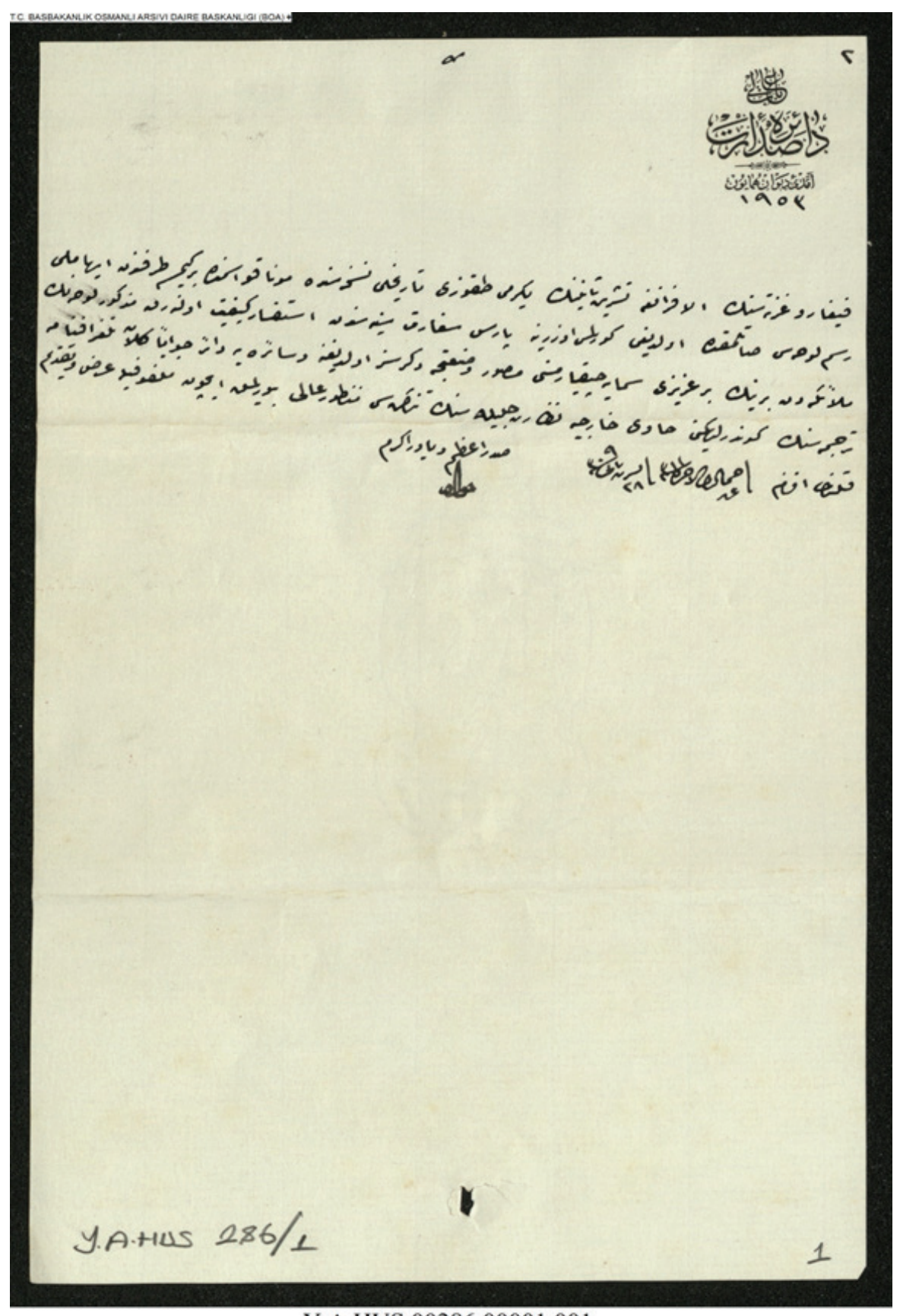

Y.A.HUS.00286.00001.001

Belge-21/2 


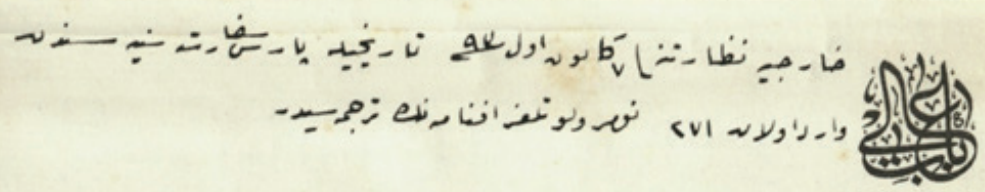

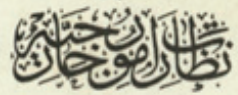

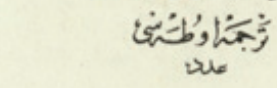

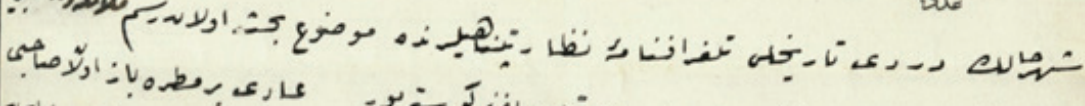

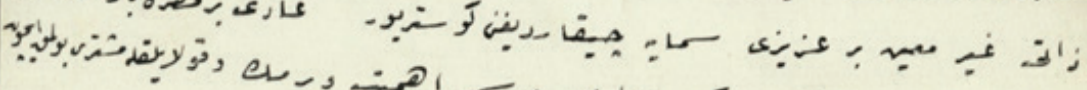

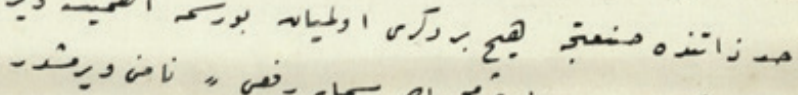

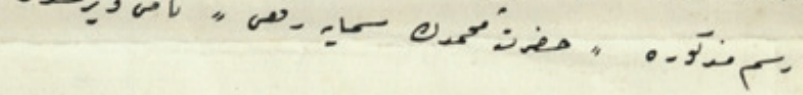

